\author{
UNIVERSIDADE DE SÃO PAULO \\ INSTITUTO DE PSICOLOGIA \\ DEPARTAMENTO DE PSICOLOGIA EXPERIMENTAL
}

EDUARDO JOSÉ DE SOUZA

Efeitos do atraso do reforço negativo na produção do desamparo aprendido em ratos

São Paulo

2018 


\section{EDUARDO JOSÉ DE SOUZA}

Efeitos do atraso do reforço negativo na produção do desamparo aprendido em ratos

Tese apresentada ao Instituto de Psicologia da Universidade de São Paulo como parte dos requisitos para a obtenção do título de Doutor em Psicologia Experimental.

Área de concentração: Psicologia Experimental

Orientadora: Profa. Dra. Maria Helena Leite Hunziker

Apoio: CAPES

São Paulo 
José de Souza, Eduardo

Efeitos do atraso do reforço negativo na produção do desamparo aprendido em ratos / Eduardo José de Souza; orientadora Maria Helena Leite Hunziker. -- São Paulo, 2018.

$94 \mathrm{f}$.

Tese (Doutorado - Programa de Pós-Graduação em Psicologia Experimental) -Instituto de Psicologia, Universidade de São Paulo, 2018.

1. desamparo aprendido. 2. reforço negativo. 3. atraso do reforço. 4. aprendizagem de fuga. 5. controle aversivo. I. Helena Leite Hunziker, Maria, orient. II. Título. 
Nome: Eduardo José de Souza

Título: Efeitos do atraso do reforço negativo na produção do desamparo aprendido em ratos

Tese apresentada ao Instituto de Psicologia da Universidade de São Paulo como parte dos requisitos para a obtenção do título de Doutor em Psicologia Experimental.

Aprovado em:

Banca Examinadora

Prof. Dr.

Instituição:

Assinatura:

Prof. Dr.

Instituição:

Assinatura:

Prof. Dr.

Instituição:

Assinatura:

Prof. Dr.

Instituição:

Assinatura:

Prof. Dr.

Instituição:

Assinatura: 


\section{AGRADECIMENTOS}

À minha família por todo o apoio. A distância de alguma forma nos aproximou.

À Daniella por todo amor nesses anos repletos de dificuldades, conquistas e descobertas. Permanecemos juntos e por isso te amo muito.

À Tatu por sua orientação ao longo deste trabalho que foi um grande desafio para mim e a quem devo muito aprendizado.

À Tauane Gehm e Cristiano Valério Santos a quem devo a gênese deste trabalho.

Aos membros do LABC pela companhia, discussões e momentos de conversa, com cada um compartilhando suas dificuldades e tentando dar apoio. Em especial, ao Amilcar, que se tornou um grande amigo. Muito obrigado pelas parcerias de todo tipo.

Ao Sílvio e Olga por terem construído as bases da minha formação acadêmica e por me fazerem enxergar o mundo de uma perspectiva especial.

Ao Noel, Edu Sá e Grazi por todo auxílio em superar dificuldades técnicas de todos os tipos. Sem a ajuda de vocês este trabalho não seria possível.

Aos membros da banca por terem aceitado debater este trabalho. 


\section{RESUMO}

Souza, E. J. (2018). Efeitos do atraso do reforço negativo na produção do desamparo aprendido em ratos. Tese de Doutorado. Instituto de Psicologia, Universidade de São Paulo, São Paulo.

A dificuldade de aprendizagem de comportamentos reforçados negativamente, após uma história de exposição a estímulos aversivos incontroláveis, é denominada "desamparo aprendido". Uma interpretação deste fenômeno é que a exposição à incontrolabilidade faz com que os sujeitos aprendam que não há relação entre suas respostas e o que ocorre nesse ambiente, o que posteriormente dificulta a aprendizagem sob reforçamento negativo (hipótese do desamparo aprendido). Outra é que, em função de reforçamento acidental, os sujeitos aprendem a ficar inativos (hipótese da inatividade aprendida). Alguns dados experimentais contradizem ambas as hipóteses, sendo os mesmos passíveis de serem interpretados por uma hipótese alternativa: a exposição à incontrolabilidade pode tornar mais relevante a contiguidade temporal entre resposta e eventos ambientais, facilitando ou dificultando novas aprendizagens (hipótese da contiguidade potencializada). Para testar tal hipótese, foram realizados três experimentos nos quais dezesseis grupos $(n=8)$ de ratos Wistar foram expostos a tratamentos com choques controláveis, incontroláveis ou nenhum choque, sendo posteriormente testados em contingência de fuga com diferentes parâmetros do atraso do reforço, tais como período temporal de atraso e sua regularidade. Os resultados obtidos indicaram que atrasos variáveis entre 450 e $750 \mathrm{~ms}$ produziram o efeito de desamparo aprendido, enquanto que atrasos fixos de 500 e $600 \mathrm{~ms}$ não produziram esse efeito de forma consistente, a despeito da exposição prévia à incontrolabilidade dos choques. Tais resultados sugerem que o atraso na liberação do reforço negativo pode ser um fator relevante para que eventos aversivos incontroláveis produzam o desamparo aprendido. São discutidas as implicações desses dados para a manutenção ou refutação das hipóteses explicativas desse efeito comportamental. A hipótese alternativa da contiguidade potencializada testada parece ser a que melhor explica os dados experimentais aqui obtidos, bem como os da literatura. Tal hipótese pode sustentar novas possibilidades de análise experimental do fenômeno denominado desamparo aprendido. Entre as possibilidades se destaca o papel que a seleção acidental do comportamento pode exercer sobre a ocorrência deste fenômeno.

Palavras-chave: desamparo aprendido, reforço negativo, atraso do reforço, aprendizagem de fuga, controle aversivo. 


\begin{abstract}
Souza, E. J. (2018). Effects of delayed negative reinforcement on the learned helplessness in rats. Tese de Doutorado. Instituto de Psicologia, Universidade de São Paulo, São Paulo.
\end{abstract}

The difficulty of learning behaviors that are negatively reinforced, after a history of exposition to uncontrollable aversive stimulus, is named "learned helplessness". An interpretation is that the exposition to uncontrollability makes the subjects learn that there is no relationship between their responses and what happens on this environment (learned helplessness hypothesis). Another interpretation is that, due to accidental reinforcement, the subjects learn to stay inactive (learned inactivity hypothesis). Some experimental data contradict both hypothesis, which are able to be interpreted using an alternative hypothesis: the exposition to uncontrollability can make the temporal contiguity between responses and environmental events more relevant, making new learnings easier or more difficult (potentiated contiguity hypothesis). In order to test such hypothesis, three experiments were carried out in which sixteen groups $(n=8)$ of Wistar rats were exposed to controllable shocks, uncontrollable shocks, and none shock. Later were tested in escape contingency with different parameters of delay of reinforcement, such as the temporal period of delay and its regularity. The obtained results indicated that delays between 450 and $750 \mathrm{~ms}$ produced the learned helplessness effect, while fixed delays of 500 and $600 \mathrm{~ms}$ did not produce this effect in a consistent manner, despite the previous exposition to the uncontrollability. Such results suggest that the delay of the negative reinforcement may be a relevant factor to produce learned helplessness. The implications of these findings to the maintenance or denial of the hypothesis that explains this behavioral effect are discussed. The alternative hypothesis of potentiated contiguity seems to be the one that best explains the experimental data obtained, as well as from literature. Such hypothesis may support new possibilities of experimental analysis of the helplessness. Between the possibilities, stands out the role that accidental selection of the behavior can exert on the occurrence of this phenomenon.

Keywords: learned helplessness, negative reinforcement, delay of reinforcement, escape, aversive control. 


\section{LISTA DE FIGURAS}

FIGURA 1. Latência média, em segundos, da resposta de fuga focinhar apresentada na sessão Teste, em sucessivos blocos de cinco tentativas, pelos sujeitos expostos a diferentes combinações de Tratamento e Teste, respectivamente: (N-I) nenhum choque / reforçamento imediato; (N-A) nenhum choque / reforçamento atrasado; (I-I) choques incontroláveis / reforçamento imediato e (I-A) choques incontroláveis / reforçamento atrasado. As linhas pontilhadas correspondem às latências médias dos sujeitos individuais; a linha contínua mostra a latência média do grupo.

FIGURA 2 Latência média, em segundos, da resposta de fuga focinhar apresentada na sessão Teste, em sucessivos blocos de cinco tentativas pelos sujeitos do Grupo I-A reunidos em dois subgrupos em função do seu desempenho nessa sessão: à esquerda estão plotadas as latências apresentadas pelos quatro sujeitos que aprenderam a resposta de fuga (latências decrescentes ao longo da sessão), e à direita as latências apresentadas pelos quatro sujeitos que não aprenderam a resposta (latências crescentes ou estáveis nos limites máximos, ao longo de toda a sessão). As linhas pontilhadas correspondem às latências médias dos sujeitos individuais; a linha contínua mostra a latência média de cada subgrupo

FIGURA 3. Latência média individual, em segundos, da resposta de fuga focinhar apresentada na sessão Teste em blocos de cinco tentativas. Cada grupo está representado no sentido horizontal, sendo identificado à direita; a ordem dos sujeitos se deu das menores latências à esquerda para as maiores latências à direita. Os sujeitos estão indicados pela notação $\mathrm{S}(n)$, onde $n$ corresponde ao número de identificação do sujeito.

FIGURA 4. Latência média, em segundos, da resposta de fuga focinhar de cada grupo apresentada na sessão Teste em sucessivos blocos de cinco tentativas: à esquerda estão plotadas as médias de cada grupo completo $(\mathrm{n}=8)$. À direita o grupo I-A aparece subdividido $(n=4)$ em função dos sujeitos terem, ou não, mostrado aprendizagem de fuga na sessão de Teste: a indicação sub1 designa a média dos animais I-A que aprenderam fuga; sub 2 representa a média dos animais I-A que não aprenderam fuga...... 
FIGURA 5. Latência média, em segundos, da resposta de fuga saltar na sessão Tratamento em sucessivos blocos de cinco tentativas apresentada pelos sujeitos expostos choques controláveis. As linhas pontilhadas correspondem às latências médias dos sujeitos individuais; a linha contínua mostra a latência média do grupo. À esquerda são apresentados os dados do Grupo C-I que posteriormente foi submetido à sessão Teste com a consequência imediata e à direita o Grupo C-A, que posteriormente passou pela sessão Teste com atraso da consequência.

FIGURA 6. Latência média, em segundos, da resposta de fuga focinhar apresentada na sessão Teste, em sucessivos blocos de cinco tentativas, pelos sujeitos expostos a diferentes combinações de Tratamento e Teste, respectivamente: (N-I) nenhum choque / reforçamento imediato; (N-A) nenhum choque / reforçamento atrasado; (C-I) choques controláveis / reforçamento imediato; (CA) choques controláveis / reforçamento atrasado; (I-I) choques incontroláveis / reforçamento imediato e (I-A) choques incontroláveis / reforçamento atrasado. As linhas pontilhadas correspondem às latências médias dos sujeitos individuais; a linha contínua mostra a latência média do grupo.

FIGURA 7. Latência média individual, em segundos, da resposta de fuga focinhar apresentada na sessão Teste em blocos de cinco tentativas. Cada grupo está representado no sentido horizontal, sendo identificado à direita; a ordem dos sujeitos se deu das menores latências à esquerda para as maiores latências à direita. Os sujeitos estão indicados pela notação $\mathrm{S}(n)$, onde $n$ corresponde ao número de identificação do sujeito.

FIGURA 8. Latência média, em segundos, da resposta de fuga focinhar de cada grupo apresentada na sessão Teste em sucessivos blocos de cinco tentativas, pelos sujeitos expostos a diferentes combinações de Tratamento e Teste, respectivamente: (N-I) nenhum choque / reforçamento imediato; (N-A) nenhum choque / reforçamento atrasado; (C-I) choques controláveis / reforçamento imediato; (CA) choques controláveis / reforçamento atrasado; (I-I) choques incontroláveis / reforçamento imediato e (I-A) choques incontroláveis / reforçamento atrasado 
FIGURA 9. Latência média, em segundos, da resposta de fuga saltar na sessão Tratamento em sucessivos blocos de cinco tentativas apresentada pelos sujeitos expostos choques controláveis. As linhas pontilhadas correspondem às latências médias dos sujeitos individuais; a linha contínua mostra a latência média do grupo. À esquerda são apresentados os dados do Grupo C-I que posteriormente foi submetido à sessão Teste com a consequência imediata e à direita o Grupo $\mathrm{C}$-A, que posteriormente passou pela sessão Teste com atraso da consequência.

FIGURA 10. Latência média, em segundos, da resposta de fuga focinhar apresentada na sessão Teste, em sucessivos blocos de cinco tentativas, pelos sujeitos expostos a diferentes combinações de Tratamento e Teste, respectivamente: (N-I) nenhum choque / reforçamento imediato; (N-A) nenhum choque / reforçamento atrasado; (C-I) choques controláveis / reforçamento imediato; (CA) choques controláveis / reforçamento atrasado; (I-I) choques incontroláveis / reforçamento imediato e (I-A) choques incontroláveis / reforçamento atrasado. As linhas pontilhadas correspondem às latências médias dos sujeitos individuais; a linha contínua mostra a latência média do grupo....

FIGURA 11. Latência média individual, em segundos, da resposta de fuga focinhar apresentada na sessão Teste em blocos de cinco tentativas. Cada grupo está representado no sentido horizontal, sendo identificado à direita; a ordem dos sujeitos se deu das menores latências à esquerda para as maiores latências à direita. Os sujeitos estão indicados pela notação $\mathrm{S}(n)$, onde $n$ corresponde ao número de identificação do sujeito.

FIGURA 12. Latência média, em segundos, da resposta de fuga focinhar de cada grupo apresentada na sessão Teste em sucessivos blocos de cinco tentativas, pelos sujeitos expostos a diferentes combinações de Tratamento e Teste, respectivamente: (N-I) nenhum choque / reforçamento imediato; $(\mathrm{N}-\mathrm{A})$ nenhum choque / reforçamento atrasado; (C-I) choques controláveis / reforçamento imediato; (C-A) choques controláveis / reforçamento atrasado; (I-I) choques incontroláveis / reforçamento imediato e (I-A) choques incontroláveis / reforçamento atrasado. 


\section{LISTA DE TABELAS}

TABELA 1. Principais características do procedimento adotado no Experimento 1...................................................................... 31

TABELA 2. Média real de atraso imposto aos sujeitos dos grupos N-A e I-A, disposta em ordem crescente

TABELA 3. Principais características do procedimento adotado no

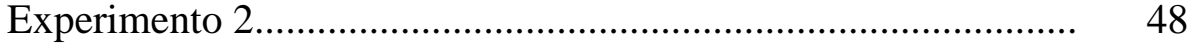

TABELA 4. Média real de atraso imposto aos sujeitos dos grupos NA, CA e IA, disposta em ordem crescente.

TABELA 5. Principais características do procedimento adotado no Experimento 3 ........................................................................... 64

TABELA 6. Média real de atraso imposto aos sujeitos dos grupos NA, CA e IA, disposta em ordem crescente. 


\section{SUMÁRIO}

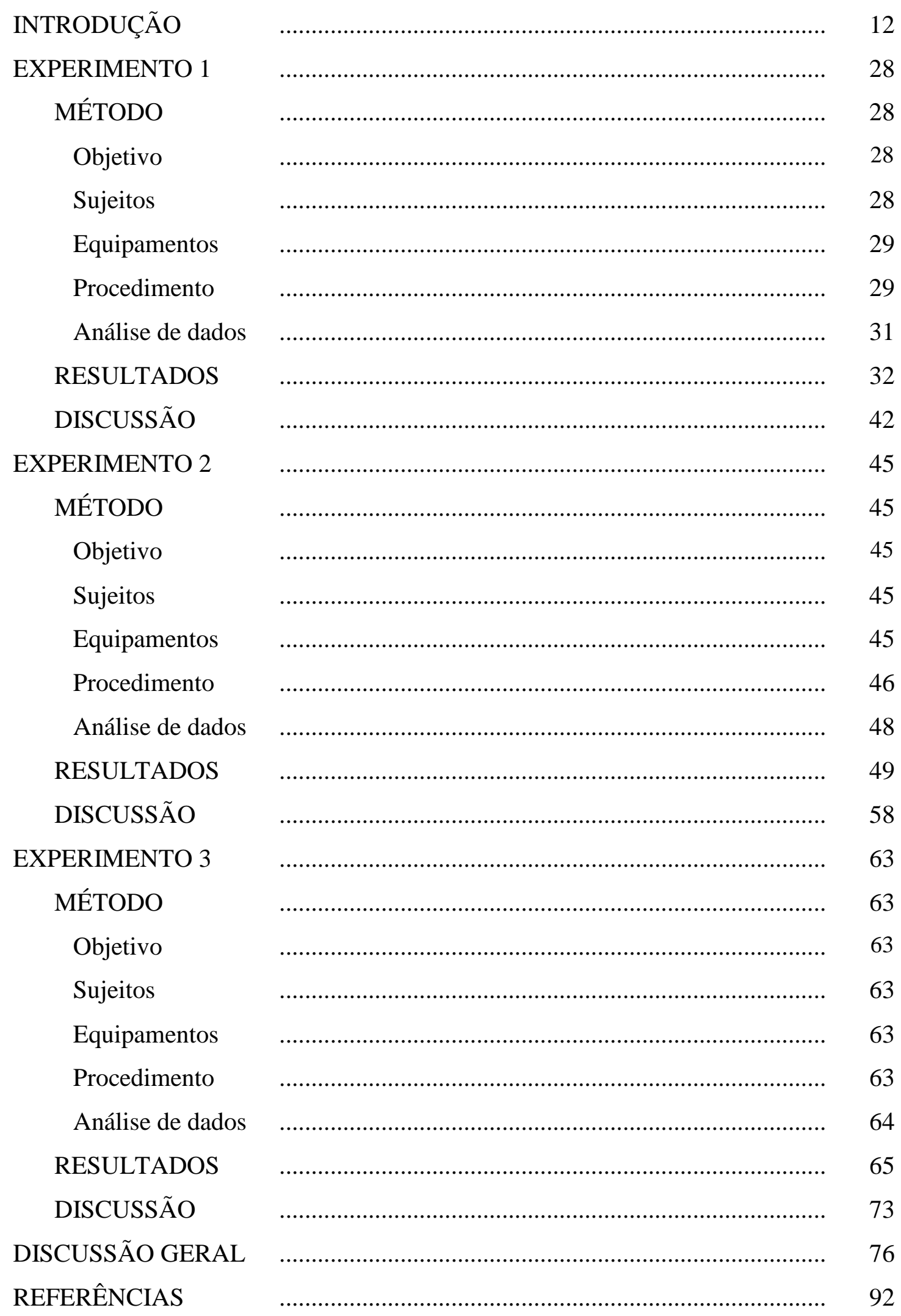


A Análise do Comportamento é uma ciência que investiga as relações entre as atividades de um organismo (resposta) e as mudanças no ambiente que antecedem e sucedem tal atividade (estímulos) (Botomé, 2013). As relações de dependência entre resposta e estímulos, denominadas contingências, têm sido enfatizadas como determinantes do comportamento (Catania, 1999; Ferster \& Skinner, 1957). No entanto, há também os processos comportamentais que decorrem da ausência dessas relações. Um exemplo é o estudo sobre comportamento supersticioso de Skinner (1948) que demonstra que a liberação de um estímulo com potencial função de reforçador positivo é capaz de fortalecer acidentalmente padrões de resposta, mesmo que apresentado de forma independente do responder. Há também os estudos sobre desamparo aprendido, desenvolvidos a partir do final da década de 1960, que demonstram que organismos expostos a eventos aversivos sem relação de dependência com uma resposta específica, apresentam posteriormente dificuldade na aprendizagem de comportamentos de fuga ou esquiva (Maier \& Seligman, 1976; Seligman \& Maier, 1967).

Tanto nos estudos acerca do comportamento supersticioso, quanto nos estudos sobre desamparo aprendido, a relação de independência entre resposta e estímulos pode ser definida operacionalmente a partir de probabilidades condicionais relativas à ocorrência desses eventos. De acordo com Maier e Seligman (1976), uma relação de independência entre resposta e estímulo é caracterizada por uma igualdade na probabilidade de um estímulo ocorrer, dada a apresentação ou não de uma resposta. Sob tal arranjo, é possível afirmar que a resposta não controla o estímulo, configurando uma situação de incontrolabilidade (ou de ausência de contingência).

No estudo que deu origem a essa linha de investigação, Seligman e Maier (1967) submeteram três grupos de cães a diferentes manipulações. Os sujeitos de um dos grupos foram expostos a choques elétricos que podiam ser interrompidos por meio da 
resposta de pressionar um painel com o focinho, ou seja, podiam controlar a duração desses choques. Outro grupo recebeu choques semelhantes (mesma intensidade, duração, intervalo de apresentação, etc.) com a única diferença que nenhuma resposta produzia efeito sobre a sua ocorrência ou duração, o que os caracterizava como incontroláveis. Um terceiro grupo permaneceu na caixa experimental pelo mesmo tempo da sessão dos demais, porém não recebeu choques. Terminada essa sessão, todos foram reconduzidos ao biotério. Após 24 horas foram submetidos a um procedimento no qual um estímulo incondicional - US, neste caso o choque, era precedidos por um estímulo luminoso, exercendo a função de estímulo condicional - CS. A emissão da resposta de saltar uma barreira na presença do CS, ou após o início do choque, evitava ou desligava o choque, caracterizando esquiva e fuga, respectivamente. Como resultado, apenas os sujeitos do grupo que recebeu choques incontroláveis não aprenderam a evitar ou desligar o choque, apresentando latências mais elevadas e maior quantidade de falhas da resposta de esquiva/fuga em comparação aos sujeitos dos outros grupos. Esse efeito foi denominado "desamparo aprendido" (learned helplessness).

Esse delineamento triádico, proposto por Seligman e Maier (1967), permitiu isolar o efeito da incontrolabilidade dos estímulos daquele produzido por sua aversividade, de forma que os resultados obtidos sugeriram que seria a incontrolabilidade dos estímulos, e não a sua aversividade, a variável independente relevante para a produção do desamparo aprendido. Outros trabalhos replicaram esses dados com diversas manipulações de diferentes variáveis independentes e dependentes, fortalecendo a generalidade e a confiabilidade do fenômeno (Hunziker, 2003, 2005).

Diferentes hipóteses foram formuladas para explicar os processos responsáveis pela interferência na aprendizagem decorrente da exposição prévia a estímulos aversivos incontroláveis. A primeira delas recebeu o mesmo nome do efeito a ser 
explicado - "desamparo aprendido" (Overmier \& Seligman, 1967). Essa hipótese propõe que durante a exposição a eventos aversivos incontroláveis, o sujeito aprende que não há relação entre as suas respostas e as alterações no ambiente que se seguem a elas. Essa aprendizagem dificulta, posteriormente, a aprendizagem oposta de dependência entre resposta e consequência, própria da contingência operante.

Uma segunda hipótese, denominada "inatividade aprendida", propõe que durante os choques incontroláveis o sujeito aprende a ficar inativo, ou seja, com baixa atividade locomotora, o que competiria com a resposta de fuga a ser emitida no teste, a qual geralmente exige grande movimentação corporal (Glazer \& Weiss, 1976a). Essa aprendizagem de inatividade ocorreria por contingências acidentais. Conforme demonstrado experimentalmente, o início do choque elicia alta atividade locomotora, que se reduz após cerca de 4 - 5s de choque (Glazer \& Weiss, 1976b). Considerando que, no geral, os estudos sobre desamparo aprendido utilizam choques incontroláveis com duração acima de 5s, Glazer e Weiss (1976a, 1976b) analisaram que, o início do choque coincide com respostas de alta atividade e o seu término com respostas de baixa atividade locomotora. Como resultado, ocorreria punição acidental de respostas de alta atividade e reforçamento negativo acidental de respostas de baixa atividade, o que levaria ao aprendizado da "inatividade" exibida no teste de fuga.

Ambas as hipóteses explicam os resultados obtidos nos estudos iniciais, mas elas permitem prever resultados distintos caso sejam exigidas no teste de fuga diferentes respostas, com diferentes topografias que envolvem diferentes graus de atividade locomotora. Portanto, a manipulação dessa variável permite o confronto dessas hipóteses. O resultado previsto pela a hipótese do desamparo aprendido é que o déficit de aprendizagem ocorreria independentemente da topografia da resposta de fuga a ser aprendida, dado que qualquer resposta requer aprendizagem de relação com suas 
consequências. Contrariamente, a hipótese de inatividade aprendida permite a previsão de que a dificuldade de aprendizagem só ocorreria se a resposta a ser aprendida exigisse alta atividade locomotora.

Alguns estudos foram realizados especificamente para fazer esse confronto de hipóteses. Hunziker (1981) propôs um procedimento que permitia ao experimentador manipular a quantidade de movimentação do sujeito durante a apresentação de choques elétricos ministrados pelo piso de uma roda de atividade que podia se apresentar em três estados diferentes: travada (impedindo o animal de andar ou correr), girando (forçandoo a correr na velocidade imposta pelo mecanismo da roda) ou livre (a roda se movimentava impulsionada apenas pelo movimento do animal, que podia caminhar ou ficar parado). Tendo o controle sobre a atividade locomotora do animal nos estágios "travada" ou "girando", pôde ser manipulada experimentalmente a probabilidade de o choque ser desligado após movimentação ou imobilidade do animal, ou após $50 \%$ de cada uma dessas condições. Como controle experimental, utilizaram-se dois grupos com a roda livre: um passou pelos mesmos choques, porém controláveis (os choques eram desligados em função de determinado número de voltas da roda) e outro que permanecia na roda pelo tempo da sessão, porém sem choques. Após 24 horas, os sujeitos foram testados numa shuttlebox onde os choques eram desligados após a emissão da resposta de saltar uma barreira. Os resultados obtidos indicaram que os sujeitos dos grupos previamente expostos aos choques controláveis ou nenhum choque aprenderam a resposta de fuga; porém, todos os expostos previamente aos choques incontroláveis apresentaram dificuldade de aprendizagem de fuga independentemente do grau de atividade locomotora permitida, ou exigida, durante esses choques. Esses resultados aparentemente são incompatíveis com a hipótese da inatividade aprendida, dado que o grau atividade locomotora apresentado durante e ao término dos choques incontroláveis 
não interferiu no déficit de aprendizagem obtido no teste. Por sua vez, eles são compatíveis com a hipótese de desamparo aprendido, pois, aparentemente, o fato do término dos choques serem independentes do comportamento dos animais foi a variável determinante do déficit de aprendizagem obtido.

Outro trabalho que confrontou ambas as hipóteses foi o estudo de Yano e Hunziker (2000), no qual ratos foram submetidos ao tratamento com choques incontroláveis ou nenhum choque, sendo manipulada a topografia da resposta de fuga utilizada no teste posterior: metade dos animais foi testada sob contingência de fuga com a resposta de saltar e outra metade com a resposta de focinhar. Sob ambas as contingências, apenas os animais expostos previamente a choques incontroláveis mostraram latências altas ao longo da sessão de teste, enquanto os demais aprenderam normalmente a resposta de fuga. Da mesma forma que no estudo anterior, esses resultados foram contrários à previsão da hipótese da inatividade aprendida, e compatíveis com a hipótese do desamparo aprendido.

No entanto, apesar desses, e muitos outros dados experimentais apontarem na direção da hipótese do desamparo aprendido (Peterson, Maier \& Seligman, 1993), há estudos que relatam resultados contrários a essa hipótese, ou seja, aprendizagem de fuga ou esquiva após a exposição a choques incontroláveis, o que contraria essa hipótese (Glazer \& Weiss, 1976a; Lee \& Maier, 1988; Maier, Albin \& Testa, 1973; Maier \& Testa, 1975; Minor, Jackson \& Maier, 1984; Santos, Gehm \& Hunziker, 2011). Embora esses estudos sejam minoria dentro dessa área de investigação, é papel do analista do comportamento identificar as variáveis responsáveis por essa fonte de variação.

Em um desses estudos, Santos et al. (2011) expuseram ratos a 60 choques incontroláveis de $1 \mathrm{~mA}, 10 \mathrm{~s}$, administrados de acordo com um esquema de tempo 
variável - VT 60s (10-110s). Posteriormente, esses animais foram expostos a duas sessões de fuga, cada uma requerendo resposta com diferente topografia (saltar e focinhar). Para metade dos sujeitos foi exigida, na primeira sessão, a resposta de fuga focinhar, e na segunda a de saltar; o inverso foi exigido dos demais sujeitos. Como resultado, foi obtido que, independente da ordem de exposição à topografia de fuga, obteve-se o desamparo aprendido apenas quando o teste foi realizado com a resposta de saltar, mas não com a de focinhar. Esses resultados foram replicados ao longo de três experimentos, a despeito das manipulações das variáveis de gênero, biotério de procedência e quantidade de tentativas no teste. Portanto, eles não replicam os dados obtidos por Yano e Hunziker (2000), sendo contrários à hipótese do desamparo aprendido. Se a exposição à incontrolabilidade fosse determinante desse efeito comportamental, por que ele ocorre se a resposta de fuga a ser aprendida for saltar, mas não se for focinhar? Em outras palavras, se o sujeito aprende que não há relação entre o que ele faz e as mudanças no ambiente, por que isso interfere posteriormente com a aprendizagem de dependência entre a resposta de saltar e o término do choque contingente a elas, mas não com a relação de dependência estabelecida com a resposta de focinhar? Por outro lado, se levarmos em conta que a resposta de saltar requer maior movimentação corporal que a de focinhar, tais resultados são compatíveis com a hipótese da inatividade aprendida.

Uma segunda questão trazida por Santos et al. (2011) diz respeito ao efeito de "reversão", apresentado na literatura como um dos indícios da validade da hipótese do desamparo aprendido. Seligman, Maier e Geer (1968) demonstraram que cães que haviam apresentado o efeito de desamparo aprendido, tinham esse efeito revertido se fossem fisicamente forçados a emitir a resposta de fuga (o experimentador puxava-os por um arreio forçando a resposta de pular uma barreira). Com isso, após seguidas 
respostas forçadas, os animais passavam a emiti-la sem auxílio. A interpretação desse resultado é que a emissão forçada da resposta coloca o sujeito em contato com a relação resposta-consequência, revertendo a aprendizagem anterior de ausência de relação entre resposta e o término do choque, adquirida durante a fase de incontrolabilidade. Contudo, no estudo de Santos et al., (2011), a aprendizagem da resposta de fuga focinhar, ocorrida na primeira sessão, colocou o sujeito em contato com a relação de contingência entre resposta e consequência, mas não alterou na sessão seguinte a probabilidade de aprendizagem de fuga com a resposta de saltar. Portanto, esses dados não confirmaram o efeito de reversão. Se a demonstração desse efeito é apresentada na literatura como um dos sustentáculos da hipótese do desamparo aprendido (Seligman, Maier \& Geer, 1968; Peterson et al., 1993), os resultados de Santos et al. (2011) enfraquecem essa hipótese.

Contudo, talvez o fato mais instigante seja a constatação de que o estudo de Santos et al. (2011) foi realizado no mesmo laboratório que produziu os resultados de Yano e Hunziker (2000). Como explicar resultados tão contraditórios produzidos por um mesmo laboratório? Buscando a resposta a essa questão, Santos et al. (2011) e Hunziker e Gehm (2010) analisaram semelhanças e diferenças entre os dois estudos, no que diz respeito a gênero, biotério de procedência, número de tentativas no teste e características do equipamento utilizado. Dado que as três primeiras variáveis se mostraram irrelevantes no estudo de Santos et al. (2011), Hunziker e Gehm (2010) focaram sua análise no tipo de equipamento de controle das variáveis experimentais: eletromecânico, utilizado por Yano e Hunziker (2000) ou digital, utilizado por Santos et al. (2011). Um aspecto que chamou a atenção foi que o equipamento eletromecânico apresenta atraso no controle dos eventos experimentais, enquanto o equipamento digital promove controle imediato. Como decorrência, o uso do equipamento eletromecânico 
impõe uma pequena latência para liberação da consequência. Ou seja, no circuito do equipamento eletromecânico, a emissão da resposta gerava um sinal elétrico (input) que era enviado a um relê produzindo o fechamento mecânico dos contatos e o envio do sinal elétrico que comandava o término do choque (output). Esse circuito input-output tinha, necessariamente, uma duração (que podia ser de cerca de um segundo ou frações de segundo) que impunha um atraso (não programado experimentalmente) entre a emissão da resposta e o término do choque. Diferentemente, o equipamento digital tem funcionamento imediato, sendo zero o intervalo entre resposta e sua consequência.

Tendo sido identificadas essas diferenças, uma pergunta a ser respondida é porque elas afetariam a ocorrência do desamparo aprendido na condição em que a reposta de fuga é focinhar, mas não a de saltar? Segundo Hunziker e Gehm (2010) e Santos et al. (2011), o motivo dessa interferência diferencial possivelmente encontra-se na topografia da resposta de fuga a ser aprendida após a exposição aos choques incontroláveis. Para entender a relevância dessa topografia, é necessário retomar aqui uma breve descrição das condições experimentais oferecidas ao rato na condição de reforçamento negativo da resposta de focinhar e de saltar descritas nesses estudos.

Em relação à resposta de focinhar, o sujeito é colocado em uma caixa de condicionamento cúbica, na qual em uma das paredes encontra-se um orifício que dá acesso a uma cuba cilíndrica com um sensor foto-elétrico, constantemente acionado por um feixe de luz, de modo que a interrupção desse feixe (geralmente devido à introdução do focinho pelo sujeito) ocasiona automaticamente o registro da resposta (ver seção Equipamento do Experimento 1 para mais detalhes sobre esse arranjo experimental). Assim, após alguns reforços negativos da resposta de focinhar, é bastante comum o sujeito ficar posicionado em frente ao operandum de forma que ao iniciar o choque, basta esticar o pescoço para introduzir o focinho no orifício da parede, desligando o 
choque. Isso permite que o intervalo temporal entre início da sua resposta e o término do choque seja muito curto.

Quando se utiliza a resposta de fuga saltar, o rato é colocado em uma caixa com dois compartimentos, separados por uma parede com um orifício central situado a $8 \mathrm{~cm}$ acima do piso, de forma que ele pode atravessar de um compartimento ao outro saltando através desse orifício. A emissão da resposta de saltar envolve, portanto, uma cadeia de respostas que requer movimentar as quatro patas deslocando seu corpo na uma direção do orifício, ficar na posição vertical em frente a ele, saltar naquela direção até atingir o piso do compartimento oposto, desligando, assim, o choque. Mesmo que o sujeito adote a postura de se posicionar em frente à passagem entre os compartimentos, ele ainda precisa impulsionar seu corpo em um salto a $8 \mathrm{~cm}$ acima do piso, atravessar a barreira que separa os compartimentos e tocar com as patas o piso do compartimento oposto. Essa cadeia comportamental é mais longa do que a exigida para focinhar, o que requer, necessariamente, mais tempo para ser completada.

Com base nessas diferenças das topografias das respostas de focinhar e saltar, Hunziker e Gehm (2010) e Santos et al. (2011) hipotetizaram que, por contraste, o atraso na consequenciação fornecido pelo equipamento eletromecânico pode ter sido mais saliente na condição de reforçamento do focinhar do que na do saltar. Em função disso, apenas a contingência envolvendo a reposta de fuga focinhar foi afetada quando nesse laboratório o equipamento eletromecânico foi substituído pelo digital. Essa interpretação muda o foco de análise sobre o efeito de desamparo aprendido, sugerindo que a incontrolabilidade do ambiente não seria a variável suficiente para a produção desse efeito. Se o atraso na consequenciação também se mostra relevante, esses autores hipotetizaram que a exposição à incontrolabilidade torna o sujeito mais sensível a outras relações que também controlam o comportamento, as quais, geralmente, são suplantadas 
pela consequenciação, quando ela existe. Dentre elas, destacou-se a relação de contiguidade temporal entre resposta e consequência. Em outras palavras, como na condição de incontrolabilidade não há relação de dependência entre resposta e consequência, o comportamento passa a ser orientado por outras relações, no caso em análise, pela contiguidade entre resposta e o evento que a segue.

Se essa hipótese estiver correta, pode-se prever que a exposição à incontrolabilidade dos choques produzirá desamparo com maior probabilidade em condições de baixa contiguidade entre resposta e consequência. Destaque-se que essa interpretação se refere a intervalos que podem ser muito curtos (cerca de um segundo ou fração de segundo), que não sendo objeto de análise podem passar despercebidos, mas que podem ser mensurados e manipulados. Essa sugestão é compatível com a literatura analítica comportamental que vem apontando o atraso da consequência como uma variável enfraquecedora da eficácia do reforçamento (Fowler \& Trapold, 1962; Keller, 1966). Portanto, essa hipótese possui lógica interna e pode ser testada.

Outros resultados, descritos na literatura, que são contrários à previsão da hipótese do desamparo aprendido, talvez possam ser igualmente explicados pela hipótese de Hunziker e Gehm (2010) e Santos et al. (2011). Por exemplo, Maier e Testa (1975) realizaram um teste de fuga e esquiva que exigia a resposta de correr sob um esquema de reforçamento em razão fixa 1 (FR1), utilizando ratos expostos anteriormente a choques incontroláveis ou a nenhum choque. Para diferentes grupos foram impostos atrasos de 1 e $3 \mathrm{~s}$, ou nenhum atraso, entre reposta e encerramento do choque. Obteve-se que o atraso da consequência pouco afetou os sujeitos não expostos a choques, mas afetou os sujeitos previamente expostos a choques incontroláveis, que apresentaram latências tanto mais elevadas quanto maior o atraso imposto. 
Em outro estudo, Minor, Jackson e Maier (1984) verificaram, ao longo de cinco experimentos, a influência do atraso do reforço negativo na produção do desamparo aprendido em conjunto com o controle por estímulos antecedentes. Eles testaram ratos em um procedimento de fuga em labirinto "Y" onde apenas a escolha do compartimento à esquerda fazia cessar o choque elétrico. Os experimentos diferiram em relação a algumas variáveis: atraso da consequência (entre $200 \mathrm{~ms}$ e $500 \mathrm{~ms}$ ) e a presença de estímulos antecedentes irrelevantes. No Experimento 1, durante o teste de fuga, quando emitida a resposta (entrar no compartimento esquerdo do labirinto) os choques eram encerrados com atraso. Como resultado, foi observado que os sujeitos dos grupos com e sem história de incontrolabilidade apresentaram latências médias da resposta de fuga decrescentes e que eram semelhantes entre si.

No quarto experimento deste estudo, além de atrasos da consequência, que vigorou para todos os grupos, foi manipulada a presença de estímulos antecedentes. Durante o teste, para um grupo com história de incontrolabilidade e outro sem tal história, uma luz era acessa no final de um dos "braços" do labirinto, de forma concomitante ao choque e permanecia acesa até o final do choque, ou nenhuma luz era apresentada. Esses eventos foram programados de forma semi-randômica e sem relação sistemática com o "braço" do labirinto que deveria ser atingido para eliminar o choque. Outros dois grupos, um deles com e outro sem história de incontrolabilidade, foi submetido ao teste de fuga com todos os "braços" do labirinto iluminados em todas as tentativas. Os resultados mostram que o único grupo que apresentou latências mais elevadas no teste de fuga (desamparo aprendido) foi aquele exposto anteriormente a choques incontroláveis e que realizou o teste de fuga no qual os compartimentos eram iluminados sem relação com a probabilidade de reforço. Com isso, os autores sugeriram que a incontrolabilidade sobre estímulos aversivos não foi suficiente para produzir o 
desamparo aprendido, sendo outras variáveis também importantes para a ocorrência do efeito, dentre elas o atraso da consequência concomitante ao controle por estímulos antecedentes irrelevantes.

Além do estudo de Minor, Jackson e Maier (1984), há outros estudos que indicam que uma história de incontrolabilidade aumenta o controle por estímulos antecedentes em contexto aversivo. Por exemplo, Lee e Maier (1988) demonstraram que o controle de estímulos pode dificultar, mas em alguns casos até facilitar, a ocorrência da resposta de fuga após a exposição a estímulos aversivos incontroláveis. O procedimento básico impunha o uso da tríade (choques controláveis, incontroláveis ou nenhum choque), com exposição posterior à contingência de fuga em um labirinto aquático. Nessa condição, o sujeito era colocado em um tanque com água, e partia de uma das extremidades do labirinto, podendo escolher entre nadar para a direita ou para a esquerda de modo a atingir uma plataforma do lado oposto do labirinto; a escolha do lado "correto" possibilitava sair da água. Ao todo, três experimentos foram realizados. Nos dois primeiros, a fuga era possível sempre do mesmo lado do labirinto, de forma que o único estímulo discriminativo era a localização direita/esquerda. Foram manipulados estímulos irrelevantes para a escolha do lado do labirinto, tais como cartões pretos e brancos posicionados de forma randômica em cada lado do labirinto, sem relação com a resposta que produziria o reforço (Experimento 1), ou cartões de uma mesma cor dispostos em ambos os lados do labirinto (Experimento 2). No Experimento 3, o lado do labirinto que possibilitava a resposta de fuga foi variado de forma randômica, sendo esse lado sinalizado sistematicamente por um cartão com uma cor específica (estímulo com função discriminativa). O critério para encerramento da sessão foi oito de dez tentativas sem erro ou no máximo 40 tentativas (nos Experimentos 1 e 2), e máximo de 60 tentativas no Experimento 3. 
Os resultados indicaram que a história de incontrolabilidade produziu uma quantidade maior de tentativas para atingir o critério de encerramento da sessão (efeito de desamparo aprendido) apenas no Experimento 1, onde os estímulos antecedentes eram irrelevantes. Ao contrário, nos Experimentos 2 e 3, com diferentes estímulos discriminativos (lateralidade ou cartões), a experiência prévia com choques incontroláveis acarretou em facilitação da aprendizagem (menor número de tentativas para atingir o critério). Nesse arranjo experimental, portanto, a história de incontrolabilidade prejudicou a aprendizagem da resposta de fuga no labirinto apenas quando estímulos antecedentes irrelevantes estavam presentes. Quando disponibilizados estímulos discriminativos relevantes, o desempenho dos animais com história de incontrolabilidade foi mais acurado que os demais.

O papel do controle do comportamento por estímulos antecedentes na ocorrência do desamparo aprendido é também um aspecto analisado na hipótese proposta por Hunziker e Gehm (2010) e Santos et al. (2011). De acordo com os autores, estando enfraquecida a relação de consequenciação, outras relações podem ser potencializadas: além da contiguidade entre resposta e estímulo que a segue, já citada anteriormente, também fica potencializado o controle por estímulos antecedentes.

Esses diversos dados experimentais forneceram subsídios para que a hipótese de Hunziker e Gehm (2010) e Santos et al. (2011) incorporasse, além do atraso do reforço, o controle por estímulos antecedentes, em contingências aversivas. Em sua formulação final, essa hipótese propõe que a exposição à incontrolabilidade sobre estímulos aversivos torna o sujeito mais sensível a outras relações de controle além da consequenciação, tais como o controle por relações de contiguidade entre resposta e consequência e o controle dessa resposta por estímulos antecedentes. 
Essa interpretação difere da hipótese do desamparo aprendido, que enfatiza apenas a relação de consequenciação na aprendizagem operante. Se a falta de consequenciação ressalta as relações de contiguidade e controle pelo antecedente, então o resultado da exposição à incontrolabilidade pode não ser necessariamente a menor aptidão funcional frente a novas contingências operantes: a depender das características da contingência, essa experiência pode dificultar ou facilitar novas aprendizagens operantes.

Os desdobramentos de uma ou outra hipótese são distintos, tanto no laboratório como na clínica (Abreu, 2011), e por isso é importante que a hipótese formulada por Hunziker e Gehm (2010) e Santos et al. (2011) seja testada experimentalmente. O presente estudo está sendo proposto com o objetivo de dar início a esses testes, especificamente visando avaliar a influência do atraso do reforço negativo na produção do desamparo aprendido. Supõe-se que através desse estudo será avaliada a relevância da contiguidade entre a resposta e o reforço negativo para a seleção da classe de respostas que produz o reforço negativo, e se a mesma é ou não alterada pela exposição prévia a choques incontroláveis. No caso dos resultados mostrarem que o atraso do reforço negativo aumenta a probabilidade de ocorrer o desamparo aprendido, então a hipótese aqui em teste teria um indício experimental a seu favor. Se o atraso se mostrar irrelevante, fica enfraquecido seu poder explicativo sobre o desamparo aprendido.

Foram realizados três experimentos seguindo a análise crítica de Hunziker (1982, 2003) relativa à precisão metodológica da mensuração da variável dependente, que no caso é a aprendizagem de fuga. Segundo essa análise, a maioria dos procedimentos empregados nos estudos sobre o desamparo aprendido incorre em inadequação no estabelecimento da contingência de fuga no teste. Os trabalhos que utilizam o esquema reforçamento em FR1 para a resposta de correr na shuttlebox (sair 
de um compartimento e chegar no compartimento oposto), mostraram latências inicias muito baixas, possivelmente em função de eliciação pelo choque. Consequentemente, mesmo os sujeitos ingênuos não apresentaram redução gradual da latência da resposta, ou seja, não mostraram evidência de controle pelo reforço negativo (Hunziker, 1977). Não havendo aprendizagem por parte desses animais ingênuos, não há, a rigor, como analisar (no grupo experimental) os efeitos dos choques incontroláveis sobre a aprendizagem de fuga. Apesar de ser uma lógica simples, Hunziker (1982; 2003) analisou criticamente como diversos estudos simplesmente ignoraram que a variável dependente dos estudos sobre desamparo é a aprendizagem operante (geralmente fuga), utilizando para demonstrar o efeito de desamparo apenas a diferença estatística entre os Grupos Experimental e Ingênuo. No que diz respeito especificamente aos objetivos do presente estudo, deve-se ressaltar que os trabalhos de Maier e Testa (1975) e Minor, Jackson e Maier (1984), que manipularam o atraso do reforço utilizaram, no teste, a resposta de correr em FR1, sem analisar essa imprecisão metodológica. De acordo com essa análise, tal imprecisão compromete a confiabilidade da análise resultante desses estudos.

Para contornar essa dificuldade, em relação ao reforçamento em FR1 da resposta de fuga correr, alguns estudos passaram a utilizar o reforçamento em FR2 para essa mesma resposta, ou seja, na shuttlebox, o sujeito deveria ir ao compartimento oposto e retornar ao inicial para eliminar o choque (Glazer \& Weiss, 1876a; Maier, Albin \& Testa, 1973; Maier e Testa, 1975). Contudo, segundo Hunziker (1982, 2003), essa contingência envolve controles conflitantes, pois o sujeito deve sair do compartimento no qual os choques iniciaram e ir ao compartimento oposto (resposta altamente provável), mas em seguida deve retornar ao compartimento onde o estímulo aversivo foi apresentado inicialmente. Isso mescla controles operantes (reforço negativo) e 
respondentes (maior aversividade do ambiente pareado ao início do choque) que controlam padrões opostos de respostas: o reforço negativo deveria aumentar a probabilidade do sujeito voltar ao compartimento inicial de forma a completar a segunda resposta que o habilita a desligar o choque; porém, o pareamento desse compartimento com o início do choque lhe dá a função de CS aversivo que controla maior probabilidade de afastar-se dele. Coerente com esse conflito, mesmo animais ingênuos emitem a resposta de correr de forma pouco sistemática, com tendência de aumentar suas latências ao longo da sessão, resultado oposto ao exigido para a aprendizagem de fuga. Novamente, sem um arranjo experimental que possibilite clara aprendizagem de fuga pelos animais ingênuos, perde-se o referencial para avaliar o desamparo aprendido nos animais expostos aos choques incontroláveis (para maiores detalhes dessa análise, ver Hunziker, 1982, 2003).

Assim, como ponto de partida para o presente estudo, fica estabelecido que o teste da hipótese aqui proposto utilizará o delineamento já demonstrado por Hunziker (1982) e Hunziker e Santos (2007) como metodologicamente adequado à investigação experimental do desamparo aprendido, que tem como base a demonstração de que o grupo de animais ingênuos deve apresentar aprendizagem de fuga, de forma que podem estabelecer o parâmetro de comparação para se avaliar o efeito das variáveis independentes em estudo sobre o comportamento do grupo experimental.

Considerando o anteriormente analisado, o presente estudo tem por objetivo testar uma das variáveis relacionadas à hipótese acima formulada, que é a influência do atraso do reforço negativo na produção do desamparo aprendido. A seguir, são apresentados os três experimentos que compõem este estudo. 


\section{EXPERIMENTO 1}

\section{MÉTODO}

\section{Objetivo}

Verificar se ratos tratados com choques incontroláveis ou nenhum choque, e posteriormente submetidos à reforçamento negativo (fuga) com um procedimento de atraso do reforço de $0,5 \mathrm{~s}$ apresentam desempenho diferencial em relação a sujeitos submetidos ao procedimento de fuga sem atraso do reforço.

\section{Sujeitos}

Foram utilizados 32 ratos albinos da linhagem Wistar, machos, experimentalmente ingênuos, de aproximadamente 90-120 dias no início do experimento. Os sujeitos foram alojados em grupos de quatro sujeitos em caixas ventiladas de polisulfona contendo maravalha (caixa Alesco, Modelo ALE.MIL.01.05), com dimensões de 48,3 cm (comprimento) x 33,7 cm (largura) x 25,3 cm (altura) e mantidos com alimento e água em regime $a d$ lib. Uma semana antes do experimento os sujeitos foram alojados individualmente em caixas de mesmo material com dimensões de $37 \mathrm{~cm}$ (comprimento) x 24,2 cm (largura) x $24 \mathrm{~cm}$ (altura), mantendo-se o regime $\mathrm{ad}$ lib. O biotério era mantido com temperatura entre 20 e $24^{\circ} \mathrm{C}$ e umidade máxima de 85\%. A iluminação foi mantida de acordo com o ciclo $12 \mathrm{~h}$ claro/escuro (8:00h/20:00h). O experimento foi realizado no período claro. 


\section{Equipamentos}

Foi utilizada uma caixa de condicionamento operante com dimensões de 21,5 $\mathrm{cm}, 21,5 \mathrm{~cm}$ e $21,0 \mathrm{~cm}$ (comprimento, largura e altura), sendo a parede frontal de acrílico transparente e as demais de alumínio. O piso era composto de barras de latão cilíndricas de $0,3 \mathrm{~mm}$ de diâmetro, distando $1,3 \mathrm{~cm}$ entre si, conectadas a um estimulador de choques com alternador de polaridades (Med Associates Inc. Modelo ENV-414S). Na parede lateral direita havia um orifício de $3,0 \mathrm{~cm}$ de diâmetro, localizado centralmente a $6,0 \mathrm{~cm}$ acima do piso onde o sujeito poderia inserir seu focinho ("focinhador"). Esse orifício conduzia a uma cuba cilíndrica de alumínio de igual diâmetro e 3,0 cm de profundidade, com um sensor foto-elétrico localizado a 1,5 cm da sua borda - constantemente acionado por um feixe de luz. A introdução do focinho nesse orifício interrompia o feixe de luz e era registrada como uma resposta de focinhar. A caixa era isolada acústica e visualmente dentro de um compartimento de madeira cúbico de $29 \mathrm{~cm}$ em cada aresta. Na parede frontal dessa caixa de isolamento havia uma abertura recoberta por acrílico transparente, que levava a iluminação ambiente ao interior da caixa e por onde era possível observar o sujeito. A umidade da sala experimental foi monitorada por um higrômetro (West Germany - Prazesions / Hygrometer) e mantida em um nível máximo de $70 \%$ por um desumidificador (ArsecMod $160 \mathrm{M3}-\mathrm{U}$ ). Um computador controlou e registrou os eventos das sessões experimentais utilizando um software especificamente desenvolvido para essa pesquisa.

\section{Procedimento}

Os sujeitos foram divididos em quatro grupos $(n=8)$ de forma equitativa em relação ao seu peso corporal. Eles foram individualmente expostos a duas sessões 
(Tratamento e Teste), espaçadas entre si por 24 hs, sendo a denominação dos grupos explicitada por duas letras relacionadas ao procedimento: a primeira indica o Tratamento (com choque incontrolável - I ou nenhum choque - N), a segunda indica o Teste de fuga (com a consequência imediata - I ou atrasada - A).

Na sessão Tratamento, os sujeitos foram colocados na caixa com o orifício do focinhador coberto por uma tampa de metal, permanecendo inoperante por toda sessão. Os sujeitos permaneceram por $180 \mathrm{~s}$ sem nenhum evento programado. Em seguida, metade dos sujeitos foram submetidos a 60 choques incontroláveis de 10s de duração fixa e 1mA de intensidade, liberados pelo piso da caixa de acordo com um esquema VT 60s (com amplitude de variação entre 10s e 110s). Nenhuma resposta do sujeito podia alterar essa distribuição de choques. Os demais sujeitos foram mantidos na caixa experimental pelo tempo médio da sessão, porém sem receber choques.

Na sessão Teste, todos os sujeitos foram individualmente colocados na mesma caixa utilizada na sessão anterior, porém com o orifício do focinhador desobstruído. Após o período de 180s sem qualquer evento programado, metade dos sujeitos expostos a cada um dos tratamentos na sessão anterior foi submetida a uma contingência de fuga na qual foram administrados 60 choques, com os mesmos parâmetros apresentados na sessão Tratamento, exceto que sua duração dependia da resposta do sujeito: o choque era interrompido imediatamente após a emissão da resposta de focinhar. A outra metade dos animais foi exposta à mesma contingência de fuga, com a única diferença que o choque era interrompido $0,5 \mathrm{~s}$ após a emissão da resposta de focinhar (atraso de $0,5 \mathrm{~s}$ ). Cada choque correspondeu a uma tentativa, sendo seu tempo de duração registrado como a latência da tentativa. Na ausência da resposta de fuga, o choque foi desligado automaticamente após 10s e esse valor registrado como a latência da tentativa, 
considerada falha. Na Tabela 1 estão apresentadas as características básicas do procedimento em cada uma das fases, para os diferentes grupos.

\section{Tabela 1}

Principais características do procedimento adotado no Experimento 1.

\begin{tabular}{|c|c|c|c|}
\hline GRUPOS & TRATAMENTO & \multicolumn{2}{|c|}{$\begin{array}{c}\text { TESTE } \\
\text { (RESPOSTA DE FOCINHAR) }\end{array}$} \\
\hline I-I & $\begin{array}{l}\text { - } 60 \text { choques } \\
\text { incontroláveis }\end{array}$ & \multirow{4}{*}{$\begin{array}{l}\text { - } 60 \text { choques } \\
\text { controláveis (fuga) } \\
\text { - VT 60s } \\
\text { - 10s máximos } \\
\text { - 1mA }\end{array}$} & - Reforçamento imediato \\
\hline I-A & $\begin{array}{l}-10 \text { s fixos } \\
-1 \mathrm{~mA}\end{array}$ & & $\begin{array}{l}\text { - Reforçamento atrasado } \\
\quad(0,5 \mathrm{~s})\end{array}$ \\
\hline N-I & \multirow{2}{*}{$\begin{array}{l}\text { - Permanência na caixa } \\
\text { experimental }\end{array}$} & & - Reforçamento imediato \\
\hline N-A & & & $\begin{array}{l}\text { - Reforçamento atrasado } \\
(0,5 \mathrm{~s})\end{array}$ \\
\hline
\end{tabular}

\section{Análise de dados}

Foram analisadas, em relação à sessão de Teste, as latências das respostas de fuga (tempo de duração de cada choque) e a quantidade de falhas de emissão dessa resposta (tentativa com choque mantido por 10s). Para a análise estatística foi utilizada a ANOVA two-way para medidas repetidas com fator de correção de Greenhouse-Gesser. Quando identificada diferença significante foi utilizado o teste Kruskal Wallis em cada bloco e o teste Mann Whitney para a comparação entre pares. Foi adotado o valor $p<$ 0,05 como indicativo de significância. 


\section{RESULTADOS}

A seguir serão apresentados os dados referentes à latência média da resposta de fuga para cada grupo de sujeitos. A análise das falhas evidenciou dados redundantes em relação aos de latência. Sendo assim, optou-se por apresentar aqui somente os dados de latência como variável dependente crítica.

A Figura 1 mostra as latências médias da resposta de fuga, agrupadas em blocos de cinco tentativas apresentadas pelos sujeitos dos quatro grupos previamente expostos a diferentes combinações de Tratamento e Teste. Na parte superior são apresentados os dados dos grupos que não receberam choque na primeira sessão e abaixo, dos grupos expostos previamente ao tratamento com choques incontroláveis; à esquerda estão os dados dos dois grupos expostos ao teste com reforço imediato e à direita os testados com reforço atrasado. Os dados individuais estão representados por linhas pontilhadas e a média do grupo representada pela linha contínua. De maneira geral, os grupos N-I, NA e I-I apresentam comportamento bastante semelhante entre si: todos os sujeitos emitiram respostas com latências sendo reduzidas gradualmente ao longo dos blocos sucessivos, o que indica mudança comportamental em função da consequência, ou seja, aprendizagem de fuga. A análise intragrupo indica que os dados individuais possuem dispersão relativamente pequena em torno da média, sendo a amplitude da dispersão maior nos blocos iniciais, ficando bastante reduzida nos blocos finais. Apesar de algumas oscilações ao longo da sessão, pode-se apontar que todos os sujeitos mostraram tendência de latências decrescentes nas exposições sucessivas às tentativas, padrão esse que se repete na média desses três grupos. Uma única pequena diferença entre esses grupos pode ser atribuída ao desempenho dos animais do Grupo I-I que foi ligeiramente 
mais estável na segunda metade da sessão, mantendo latências da resposta de fuga em torno de $2 \mathrm{~s}$.
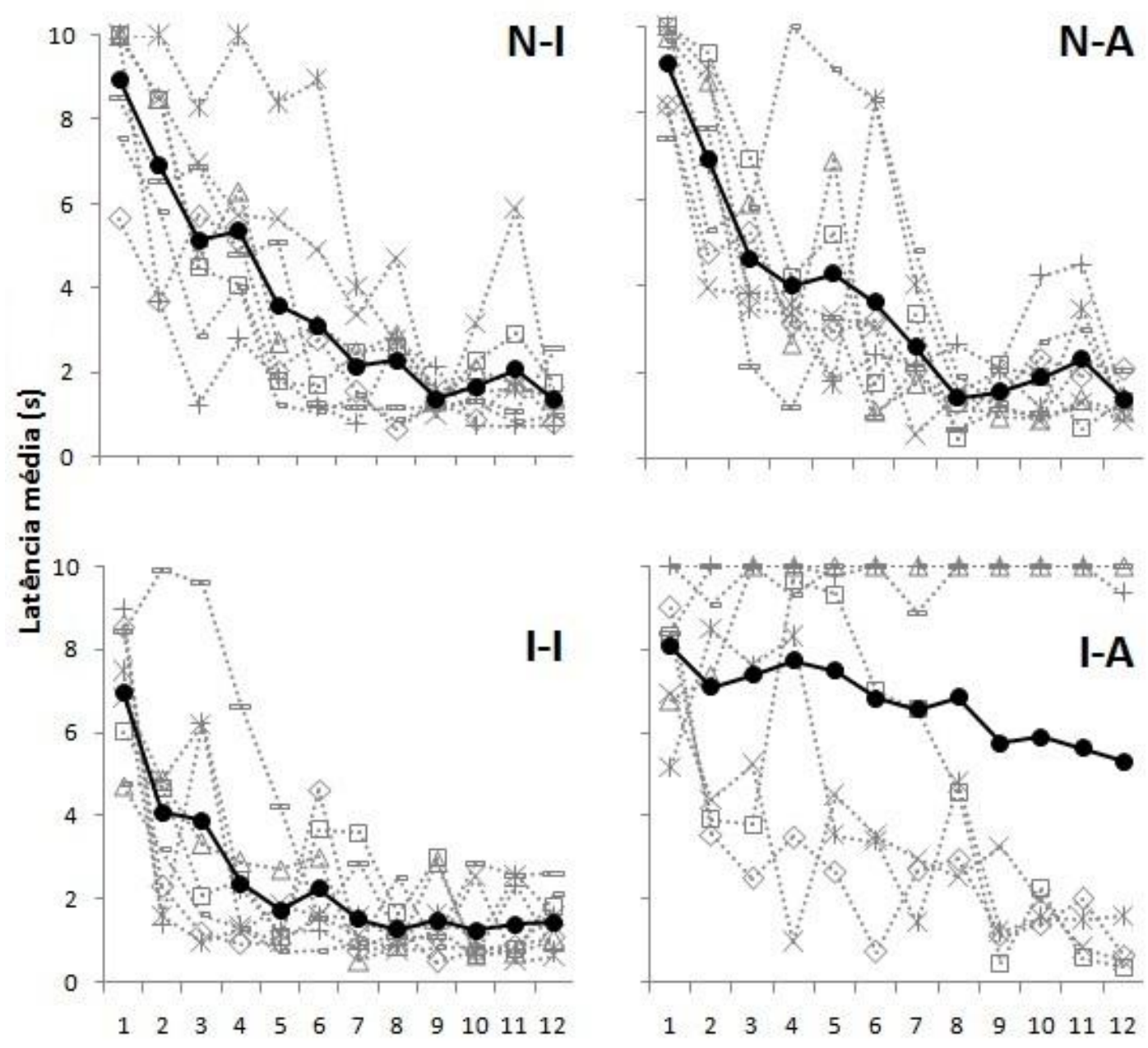

Blocos de 5 tentativas

Figura 1. Latência média, em segundos, da resposta de fuga focinhar apresentada na sessão Teste, em sucessivos blocos de cinco tentativas, pelos sujeitos expostos a diferentes combinações de Tratamento e Teste, respectivamente: (N-I) nenhum choque / reforçamento imediato; (N-A) nenhum choque / reforçamento atrasado; (I-I) choques incontroláveis / reforçamento imediato e (I-A) choques incontroláveis / reforçamento atrasado. As linhas pontilhadas correspondem às latências médias dos sujeitos individuais; a linha contínua mostra a latência média do grupo.

Desempenho bastante diferentes foi mostrado pelos animais do Grupo I-A, com destaque para a grande variabilidade individual, com desempenhos contrastantes entre 
si. Tal variabilidade sugere a composição de dois subgrupos: um composto por quatro sujeitos que apresentaram padrão de aprendizagem de fuga, ou seja, redução gradual da latência da resposta ao longo da sessão, e outro pelos quatro animais que não apresentaram esse padrão, mostrando latências altas (geralmente no patamar máximo de 10s) durante toda a sessão. Consequentemente, o dado médio do grupo (linha contínua) é pouco representativo do desempenho dos sujeitos individuais.

Esses mesmos dados são reapresentados na Figura 2, separando-se os dois subgrupos: dados individuais e média dos animais que aprenderam a resposta de fuga (à esquerda) e dos que não aprenderam tal resposta (à direita). Os quatro sujeitos que aprenderam a resposta de fuga apresentaram tendência geral de redução das latências ao longo da sessão, embora com grande variação, tanto intra como entre sujeitos, até o sétimo bloco de tentativas; nos blocos posteriores esses animais mostraram queda acentuada da latência e desempenho uniforme entre si até o final da sessão. O dado médio desse subgrupo é representativo dos padrões individuais e semelhante ao mostrado pelos demais grupos analisados anteriormente. Padrão totalmente destoante dos demais foi mostrado pelos quatro sujeitos que compuseram o segundo subgrupo: apesar de algumas respostas de fuga terem sido emitidas nos blocos iniciais, essa emissão não foi mantida nos blocos posteriores, o que é indicado pelas sucessivas latências máximas que configuram falhas. Esse padrão ocorreu com pouca variabilidade entre os sujeitos de forma que a latência média deste subgrupo é representativa dos dados individuais: alta nos dois blocos iniciais (acima de 8s) e mantida praticamente no patamar máximo (10s) até o final da sessão. Portanto, pode-se afirmar que esses animais não aprenderam a resposta de fuga. 

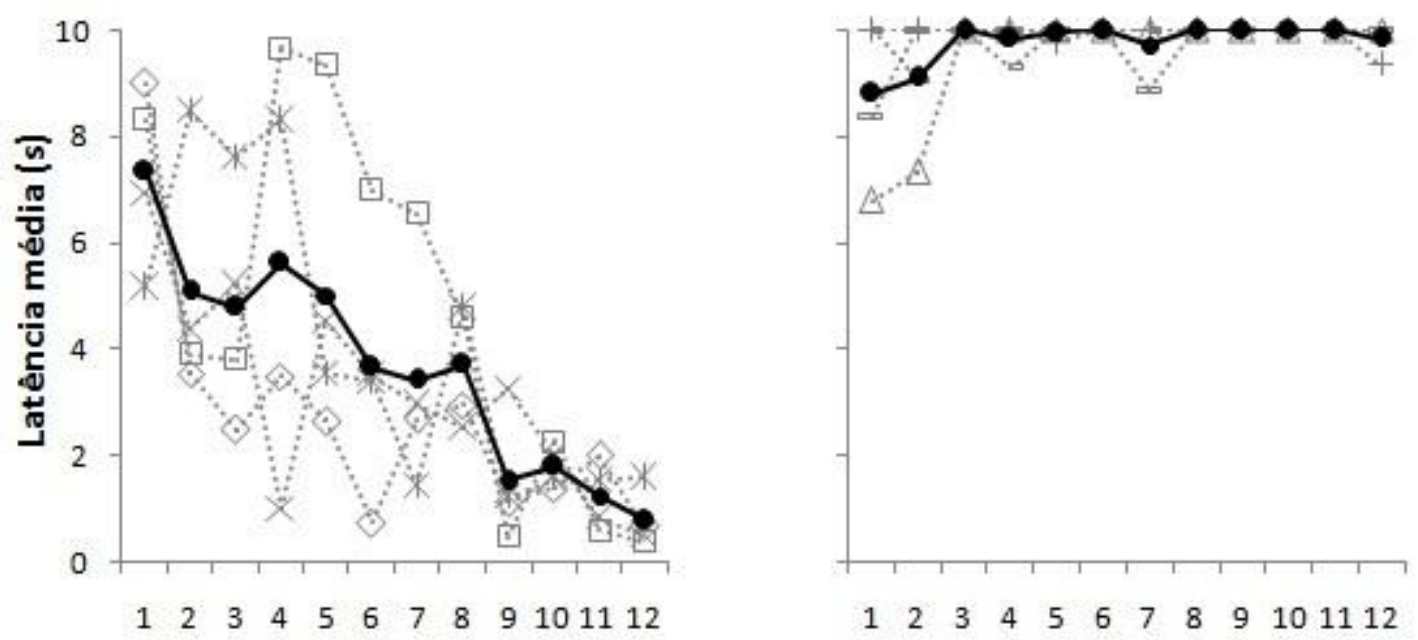

\section{Blocos de 5 tentativas}

Figura 2. Latência média, em segundos, da resposta de fuga focinhar apresentada na sessão Teste, em sucessivos blocos de cinco tentativas pelos sujeitos do Grupo I-A reunidos em dois subgrupos em função do seu desempenho nessa sessão: à esquerda estão plotadas as latências apresentadas pelos quatro sujeitos que aprenderam a resposta de fuga (latências decrescentes ao longo da sessão), e à direita as latências apresentadas pelos quatro sujeitos que não aprenderam a resposta (latências crescentes ou estáveis nos limites máximos, ao longo de toda a sessão). As linhas pontilhadas correspondem às latências médias dos sujeitos individuais; a linha contínua mostra a latência média de cada subgrupo.

A análise mais minuciosa do desempenho de cada sujeito pode ser feita a partir dos dados mostrados na Figura 3, onde cada linha mostra os oito sujeitos de cada grupo ordenados de forma crescente em função das suas latências ao longo dos blocos sucessivos. Na parte superior direita de cada gráfico está a numeração que identifica o sujeito dentro do seu grupo. Com algumas pequenas variações, todos os sujeitos dos Grupos N-I, N-A e I-I apresentaram padrão bastante similar entre si: latências com tendência decrescente ao longo da sessão. Em relação aos animais do Grupo I-A, fica evidenciado dois padrões: enquanto os Sujeitos 1, 4, 5 e 2 repetiram o padrão mostrado pelos animais dos demais grupos, os Sujeitos 3, 6, 8 e 7 mostraram latências muito elevadas durante toda a sessão, frequentemente no patamar máximo, o que denota não emissão da resposta de fuga (falha). Importante destacar que esses dados indicam que 
todos os sujeitos do Grupo I-A emitiram a resposta de fuga ao menos uma vez ao longo da sessão Teste (latência abaixo de 10s), tendo experimentado, portanto, ao menos uma vez, o término do choque contingente a essa resposta. 

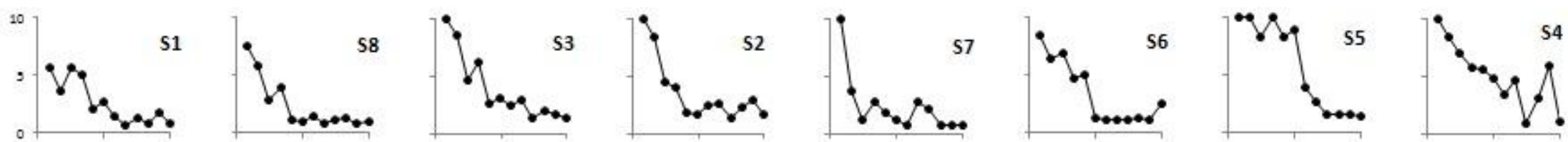

$\mathrm{N}-\mathrm{I}$
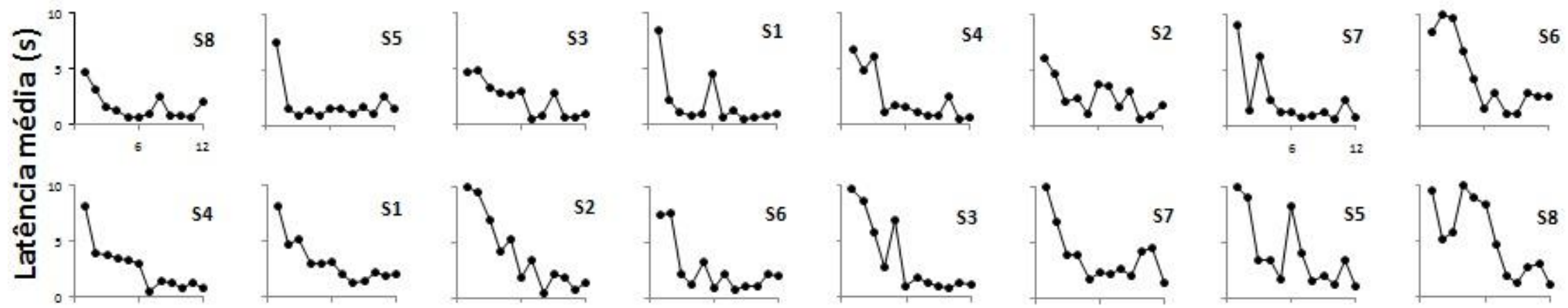

I-I
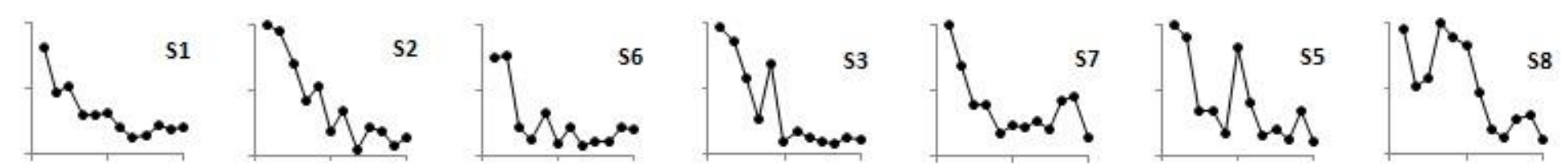

N-A
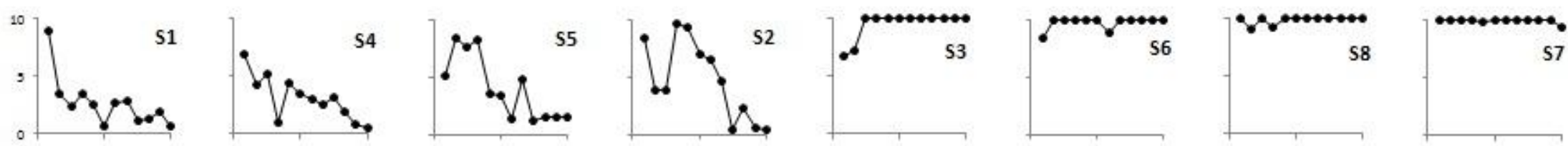

I-A

\section{Blocos de 5 tentativas}

Figura 3. Latência média individual, em segundos, da resposta de fuga focinhar apresentada na sessão Teste em blocos de cinco tentativas. Cada grupo está representado no sentido horizontal, sendo identificado à direita; a ordem dos sujeitos se deu das menores latências à esquerda para as maiores latências à direita. Os sujeitos estão indicados pela notação $\mathrm{S}(n)$, onde $n$ corresponde ao número de identificação do sujeito. 
A Figura 4 reagrupa os dados de latência média dos grupos, facilitando a comparação visual entre eles. Ao lado esquerdo estão apresentados os dados dos quatro grupos completos, e do lado direito, os mesmos dados, porém com a subdivisão do Grupo I-A entre os que aprenderam (sub 1) ou não aprenderem a resposta de fuga (sub 2). Essa representação conjunta confirma que os Grupos N-I, N-A e I-A apresentam, em média, um padrão muito semelhante entre si, típico de aprendizagem de fuga. As diferenças entre eles são pequenas e quase exclusivamente nos blocos iniciais, com o Grupo I-I apresentando latência média ligeiramente mais baixa que os demais. Contrasta apenas o Grupo I-A que, com exceção dos dois primeiros blocos, em que mostrou padrão semelhante aos demais grupos, no restante da sessão apresentou latências médias elevadas (acima ou próximas de 6s) com redução pouco acentuada no decorrer das tentativas. Contudo, mesmo esse pequeno declínio médio não é representativo do grupo, sendo influenciado pelo padrão de apenas metade dos sujeitos, conforme pode ser visto na parte direita dessa figura: a média dos animais que aprenderam fuga (sub 1) se sobrepõe às dos demais grupos, enquanto a dos que não aprenderam fuga (sub 2) é totalmente destoante, com tendência crescente e manutenção nos patamares máximos de latência de fuga. 

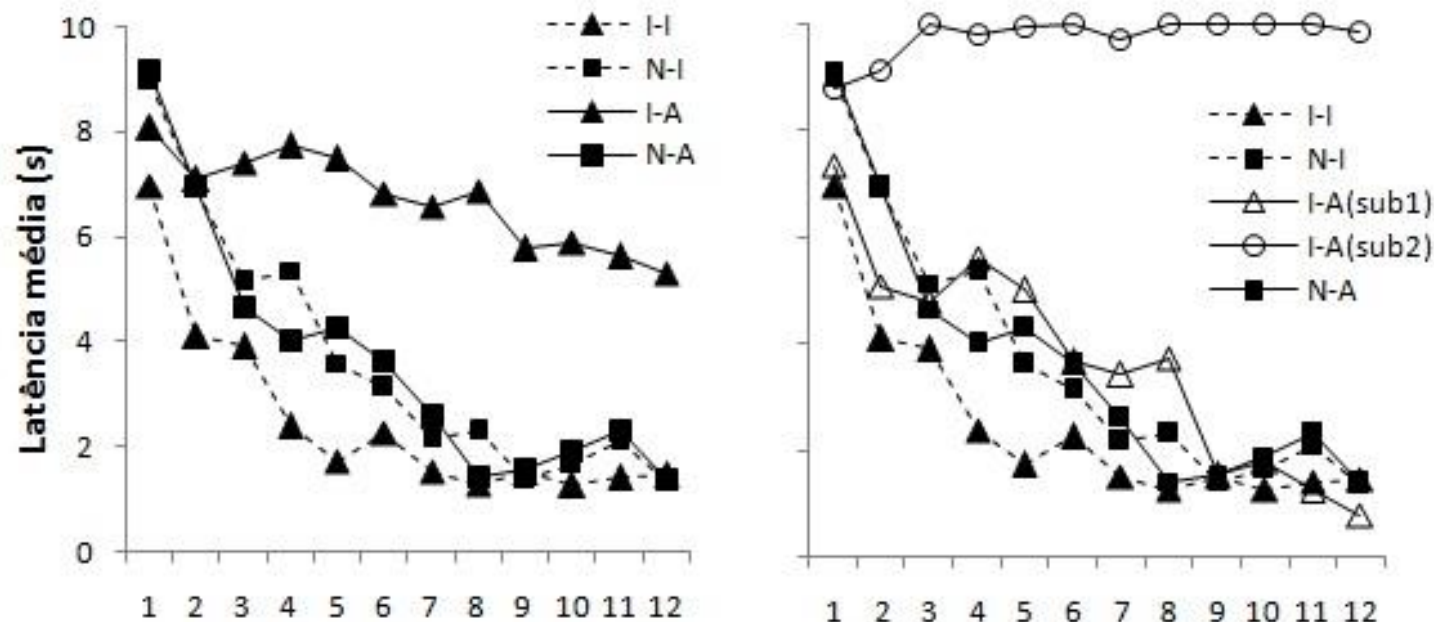

Blocos de 5 tentativas

Figura 4. Latência média, em segundos, da resposta de fuga focinhar de cada grupo apresentada na sessão Teste em sucessivos blocos de cinco tentativas: à esquerda estão plotadas as médias de cada grupo completo $(n=8)$. À direita o grupo I-A aparece subdividido $(n=4)$ em função dos sujeitos terem, ou não, mostrado aprendizagem de fuga na sessão de Teste: a indicação sub1 designa a média dos animais I-A que aprenderam fuga; sub 2 representa a média dos animais I-A que não aprenderam fuga.

A análise estatística indica como significantes as diferenças mostradas pelos grupos em função das tentativas $[\mathrm{F}(5,143)=41,67, p<0,001]$, confirmando estatisticamente que houve aprendizagem de fuga. Também houve diferenças como função do tratamento recebido pelo grupo $[\mathrm{F}(3,28)=7,54, p=0,001]$ e da interação entre tratamento e tentativas $[\mathrm{F}(15,143)=2,81, p=0,001]$. No entanto, o teste post hoc de comparação entre pares de grupos indicou que as diferenças não foram consistentes ao longo da sessão. As diferenças foram significantes somente em cinco dos 12 blocos de tentativas. Desses cinco blocos, em apenas um deles (bloco 8), o Grupo I-A se distinguiu de todos os outros grupos $\operatorname{com} p=0,001$.

Conforme mostrado anteriormente, a análise estatística do Grupo I-A como um todo é prejudicada pela diversidade vista nesse grupo. Assim, foi realizada a análise estatística separadamente para os dois subgrupos, comprando-os entre si. Obteve-se que 
as diferenças entre os dois subgrupos foi altamente significante $[\mathrm{F}(1,6)=174,8, p<$ $0,001]$, sem diferenças em função das tentativas como um todos $[\mathrm{F}(3,17)=2,96, p>$ 0,05], mas com interação entre subgrupo e tentativas $[\mathrm{F}(3,17)=4,84, p=0,014]$. Esse resultado estatístico confirma o que foi apontado anteriormente por inspeção visual.

Quanto ao atraso imposto para o reforço em dois dos grupos testados, o procedimento de nonresetting delay, conforme sistematização apresentada por Lattal (2010) implica que algumas variações na contingência planejada possam ocorrer. Ou seja, embora a contingência estivesse programada para desligar o choque $0,5 \mathrm{~s}$ após a emissão da resposta de focinhar, se o sujeito apresentasse outra resposta antes de completar esse intervalo, o atraso não era reiniciado; consequentemente, esta resposta seria seguida pelo intervalo restante, menor que $0,5 \mathrm{~s}$. A Tabela 2 mostra o atraso médio real ao qual foi exposto cada sujeito dos grupos N-A e I-A, organizados em ordem crescente de atraso para cada sujeito dos grupos. Pode-se verificar que, na média da sessão, os intervalos de atraso ficaram bastante próximos do planejado: 0,48 e 0,47s com desvios padrão de 0,03 e 0,05, nos Grupos N-A e I-A, respectivamente. Considerando-se as variações individuais, obteve-se que a menor média de atraso foi de 0,42 s no Grupo N-A e 0,36 s no Grupo I-A. 
Tabela 2

Média real de atraso imposto aos sujeitos dos grupos N-A e I-A, disposta em ordem crescente.

\begin{tabular}{ccccc}
\hline GRUPO & $\begin{array}{c}\text { MÉDIA REAL DE } \\
\text { ATRASO }\end{array}$ & SUJEITO & $\begin{array}{c}\text { MÉDIA DO } \\
\text { GRUPO }\end{array}$ & $\begin{array}{c}\text { DESVIO } \\
\text { PADRÃO }\end{array}$ \\
\hline \multirow{4}{*}{ N-A } & 0,42 & 6 & & \\
& 0,46 & 1 & & \\
& 0,49 & 8 & 0,48 & 0,03 \\
& 0,49 & 3 & & \\
& 0,49 & 4 & & \\
\hline \multirow{4}{*}{ I-A } & 0,49 & 2 & & \\
& 0,49 & 5 & & \\
& 0,50 & 7 & 0,47 & \\
& 0,36 & 2 & & \\
& 0,45 & 4 & & \\
& 0,47 & 1 & & \\
& 0,48 & 5 & & \\
& 0,50 & 6 & & \\
& 0,50 & 8 & & \\
\end{tabular}




\section{DISCUSSÃO}

Os resultados obtidos com os sujeitos do Grupo N-I, que não haviam tido contato com choques e que foram reforçados imediatamente, mostraram padrão típico de aprendizagem de fuga com a resposta de focinhar replicando os dados anteriormente relatados (Santos et al., 2011; Yano \& Hunziker, 2000). Além disso, demonstraram que o atraso programado de $0,5 \mathrm{~s}$ não influenciou, por si, a aprendizagem de fuga. Tanto os sujeitos do Grupo N-I (reforçados imediatamente), como do Grupo N-A (reforçados com atraso), aprenderam igualmente a resposta de fuga focinhar. Tal resultado é coerente com estudos que mostram que a aquisição e manutenção da resposta operante pode ocorrer mesmo com breves atrasos da consequência, sendo que os efeitos disruptivos sobre o comportamento se acentuam conforme o aumento no valor do atraso (Haaren, 1992; Wilkenfield, Nickel, Blakely \& Poling, 1992). Aparentemente, o valor de atraso aqui manipulado não foi suficiente para interferir na aprendizagem operante, dado que o padrão de aprendizagem de fuga foi semelhante nos dois grupos não expostos a choques.

Os resultados dos sujeitos dos grupos não expostos a choques N-I e N-A serviram como parâmetro de comparação para se avaliar os efeitos da história de incontrolabilidade sobre o choque. Os dados do Grupo I-I mostram que sem atraso no reforço liberado na sessão de teste, essa história não interferiu na aprendizagem da reposta fuga focinhar, ou seja, não produziu o efeito de desamparo aprendido. Esse resultado replica os relatos de Santos et al. (2011), que foram contrários aos de Yano e Hunziker (2000). Teoricamente, eles são contrários a hipótese do desamparo aprendido que prediz que a exposição a choques incontroláveis deveria produzir o efeito de dificultar a aprendizagem de um novo operante (Maier \& Seligman, 1976), o que não 
foi observado no presente estudo. Os dados aqui relatados mostram que a resposta de focinhar foi claramente controlada pela sua consequência (término do choque), o que a caracteriza como operante (Catania, 1999). Sendo assim, não se obteve o efeito de desamparo pelos animais previamente expostos a choques incontroláveis.

O dado original deste estudo está no fato de que a introdução do atraso do reforço negativo interferiu no comportamento de metade dos animais com história de incontrolabilidade. Os dados do Grupo I-A indicam que quatro sujeitos apresentaram efeito de desamparo aprendido acentuado, tornando-se comparáveis aos resultados descritos por Yano e Hunziker (2000). Se, por um lado, esse resultado aparentemente fortalece a hipótese proposta por Hunziker e Gehm (2010) e Santos et al. (2011), ele traz uma nova questão: por que apenas metade dos sujeitos previamente expostos aos choques incontroláveis foi afetada pelo atraso do reforço negativo na sessão de Teste?

Uma interpretação é de que o valor de atraso de 0,5 s tenha sido limítrofe, o que fez com que o efeito tenha sido significativo para alguns sujeitos, mas não para outros. Essa interpretação pode ser experimentalmente testada aumentando-se o valor do atraso e verificando se os seus efeitos abrangeriam mais sujeitos.

Apesar dos resultados pouco uniformes do Grupo I-A, eles tornam promissora a hipótese proposta por Hunziker e Gehm (2010) e Santos et al. (2011) como alternativa para explicar o desamparo aprendido. No entanto, se o objetivo da presente tese é verificar se tal variável pode interferir na ocorrência do desamparo aprendido, se faz necessária a utilização do procedimento da tríade, para se certificar de que os efeitos observados se devem não apenas a exposição ao estímulo aversivo em si, mas é função do grau de controle exercido sobre o estímulo aversivo. 
Em suma, com este experimento foi possível encontrar indícios de que a história de incontrolabilidade pode afetar diferencialmente a sensibilidade ao atraso do reforço negativo, e que essa variável talvez possa explicar as discordâncias descritas na literatura por Yano e Hunziker (2000) e Santos et al. (2011). No entanto, para possibilitar que tal efeito seja detectado de forma mais evidente, os atuais resultados sugerem um novo experimento com valor do atraso do reforço maior, além de utilizar o procedimento triádico, convencional dos estudos sobre desamparo aprendido, o que permite isolar experimentalmente o controle sobre os estímulos aversivos como uma variável que afeta a ocorrência do desamparo aprendido. O Experimento 2, descrito a seguir, foi delineado para atender esses requisitos. 


\section{EXPERIMENTO 2}

\section{MÉTODO}

\section{Objetivo}

Verificar se ratos tratados com choques controláveis, incontroláveis ou nenhum choque, e posteriormente submetidos à reforçamento negativo (fuga) com um procedimento de atraso do reforço de 0,6s apresentam desempenho diferencial em relação a sujeitos submetidos ao procedimento de fuga sem atraso do reforço.

\section{Sujeitos}

Foram utilizados 48 ratos albinos da linhagem Wistar, com as mesmas características e alojados sob as mesmas condições dos sujeitos do Experimento1A.

\section{Equipamentos}

Foram utilizados os mesmos equipamentos do Experimento 1, com exceção da caixa experimental utilizada na sessão de tratamento. Foi utilizada uma shuttlebox medindo 50,0 x 15,5 x 20,0 cm (comprimento, largura e altura), construída em acrílico preto fosco, com exceção da parede frontal que era de acrílico transparente. No seu comprimento, a caixa era dividida em dois compartimentos de igual tamanho por uma parede também de acrílico preto fosco que continha um orifício de $7,5 \mathrm{~cm}$ de altura e $6,0 \mathrm{~cm}$ de largura, localizado a $8,0 \mathrm{~cm}$ do piso e através do qual o sujeito poderia saltar de um compartimento ao outro. O piso era composto de barras de latão cilíndricas de 
0,3 $\mathrm{mm}$ de diâmetro, distando $1,3 \mathrm{~cm}$ entre si. Na base do orifício também estavam localizadas duas barras cilíndricas de latão (uma de cada lado do orifício). O piso de cada lado do compartimento era independente e dotado de um sistema de molas que possibilitava a inclinação do piso quando o sujeito se situasse em um dos lados do compartimento. Essa inclinação ativava um microswitch, que registrava automaticamente a presença do sujeito no lado correspondente da caixa. A caixa era isolada acústica e visualmente dentro de um compartimento de madeira de dimensões $63 \mathrm{~cm}, 71 \mathrm{~cm}$ e $35 \mathrm{~cm}$ (comprimento, largura e altura). Os choques elétricos foram administrados através das barras cilíndricas do piso e da base do orifício, a partir de geradores conectados a alternadores de polaridades (shock scrambler) de fabricação BRS Foringer modelo 901.

\section{Procedimento}

Os sujeitos foram divididos em seis grupos $(n=8)$ de forma equitativa em relação ao seu peso corporal. Eles foram individualmente expostos a duas sessões (Tratamento e Teste), espaçadas entre si por $24 \mathrm{hs}$, sendo a denominação dos grupos explicitada por duas letras correspondentes ao procedimento: A primeira indica o Tratamento (choque controlável - C, incontrolável - I, ou nenhum choque - N), a segunda indica o Teste de fuga (com consequência imediata - I ou atrasada - A).

$\mathrm{Na}$ sessão Tratamento, os sujeitos foram colocados na shuttlebox e permaneceram por 180s sem nenhum evento programado. Em seguida, os animais de dois grupos foram submetidos a 60 choques de 10 s de duração máxima e $1 \mathrm{~mA}$ de intensidade, liberados pelo piso da caixa de condicionamento de acordo com um esquema VT 60s (com amplitude de variação entre 10s e 110s). A resposta de saltar 
para o compartimento adjacente encerrava o choque. Esses grupos foram denominados Controláveis (C). Outros dois grupos de sujeitos foram submetidos a essa sessão estando a shuttlebox com o orifício de comunicação entre os compartimentos bloqueado. Esses grupos foram denominados Incontroláveis (I). Eles foram acoplados aos pares aos animais do Grupo $\mathrm{C}$, de modo que os choques foram recebidos pelo par com as mesmas características (quantidade, intensidade, duração e intervalo), com a única diferença que as respostas dos sujeitos do Grupo I não tinham qualquer consequência: os choques eram desligados seguindo a duração determinada pelo comportamento do seu par do Grupo C. Portanto, para os animais do Grupo I os choques foram incontroláveis. Os dois grupos de animais restantes não receberam choque, apenas permaneceram na caixa experimental pelo mesmo período de tempo dos demais sujeitos, constituindo os Grupos Nenhum Choque (N).

Na sessão Teste, todos os animais foram individualmente submetidos à contingência de fuga para a resposta de focinhar, semelhante à descrita no Experimento 1, sendo metade testada com atraso do reforço (Grupos C-A, I-A e N-A) e metade com reforço imediato (Grupos C-I, I-I e N-I). A diferença em relação ao experimento anterior é que neste estudo o intervalo entre a emissão da resposta e o término do choque foi de $0,6 \mathrm{~s}$ (atraso do reforço). Na Tabela 3 estão apresentadas as características básicas desse procedimento. 


\section{Tabela 3}

Principais características do procedimento adotado no Experimento 2.

\begin{tabular}{|c|c|c|c|}
\hline GASES & TRATAMENTO & \multicolumn{2}{|c|}{$\begin{array}{c}\text { TESTE } \\
\text { (RESPOSTA DE FOCINHAR) }\end{array}$} \\
\hline C-I & \multirow{2}{*}{$\begin{array}{l}\text { - } 60 \text { choques controláveis } \\
\text { (fuga) } \\
\text { - VT 60s } \\
\text { - } 10 \text { s máximos } \\
\text { - } 1 \mathrm{~mA} \\
\text { - resposta de saltar }\end{array}$} & \multirow{6}{*}{$\begin{array}{l}\text { - } 60 \text { choques } \\
\text { controláveis } \\
\text { (fuga) } \\
\text { - VT 60s } \\
\text { - } 10 \text { s máximos } \\
\text { - 1mA }\end{array}$} & - Reforçamento imediato \\
\hline C-A & & & - Reforçamento atrasado $(0,6 \mathrm{~s})$ \\
\hline I-I & \multirow{2}{*}{$\begin{array}{l}\text { - } 60 \text { choques } \\
\text { incontroláveis } \\
\text { - Acoplado } \\
\text { - 1mA }\end{array}$} & & - Reforçamento imediato \\
\hline I-A & & & - Reforçamento atrasado $(0,6 \mathrm{~s})$ \\
\hline N-I & \multirow{2}{*}{$\begin{array}{l}\text { - Permanência na caixa } \\
\text { experimental }\end{array}$} & & - Reforçamento imediato \\
\hline $\mathrm{N}-\mathrm{A}$ & & & - Reforçamento atrasado $(0,6 \mathrm{~s})$ \\
\hline
\end{tabular}

\section{Análise de dados}

Foram utilizadas as mesmas medidas e testes estatísticos do Experimento 1. 


\section{RESULTADOS}

Os dados a seguir serão apresentados de acordo com as fases do experimento. Sendo assim, inicialmente serão apresentados os dados da sessão Tratamento dos sujeitos que receberam choques controláveis (Grupos C-I e C-A). Posteriormente serão apresentados os dados referentes à sessão Teste de todos os grupos.

A Figura 5 mostra as latências médias das respostas de saltar apresentadas na sessão de Tratamento pelos sujeitos que puderam controlar a duração dos choques nessa sessão: à esquerda dados dos animais do Grupo C-I e à direita dos animais do Grupo CA. Em ambos os grupos é possível perceber que as latências foram decrescentes ao longo da sessão, o que indica que todos os sujeitos exerceram controle sobre o encerramento do choque. A latência média do Grupo C-I nos blocos iniciais é mais elevada em comparação à latência média inicial do Grupo C-A, ficando, respectivamente, próxima de $6 \mathrm{~s}$ e $4 \mathrm{~s}$. A variabilidade intragrupo também foi bastante semelhante entre ambos, havendo em cada grupo apenas um sujeito que difere um pouco dos demais na primeira metade da sessão, mas todos convergindo para um mesmo padrão de respostas com baixas latências nos blocos finais. Portanto, pode-se perceber que ambos os grupos estavam compostos de forma bastante equilibrada, sem diferenças que sugerissem qualquer viés na sua composição. Além disso, esses animais cumpriram o requisito de terem, de fato, exercido controle sobre a duração dos choques na sessão de Tratamento. 

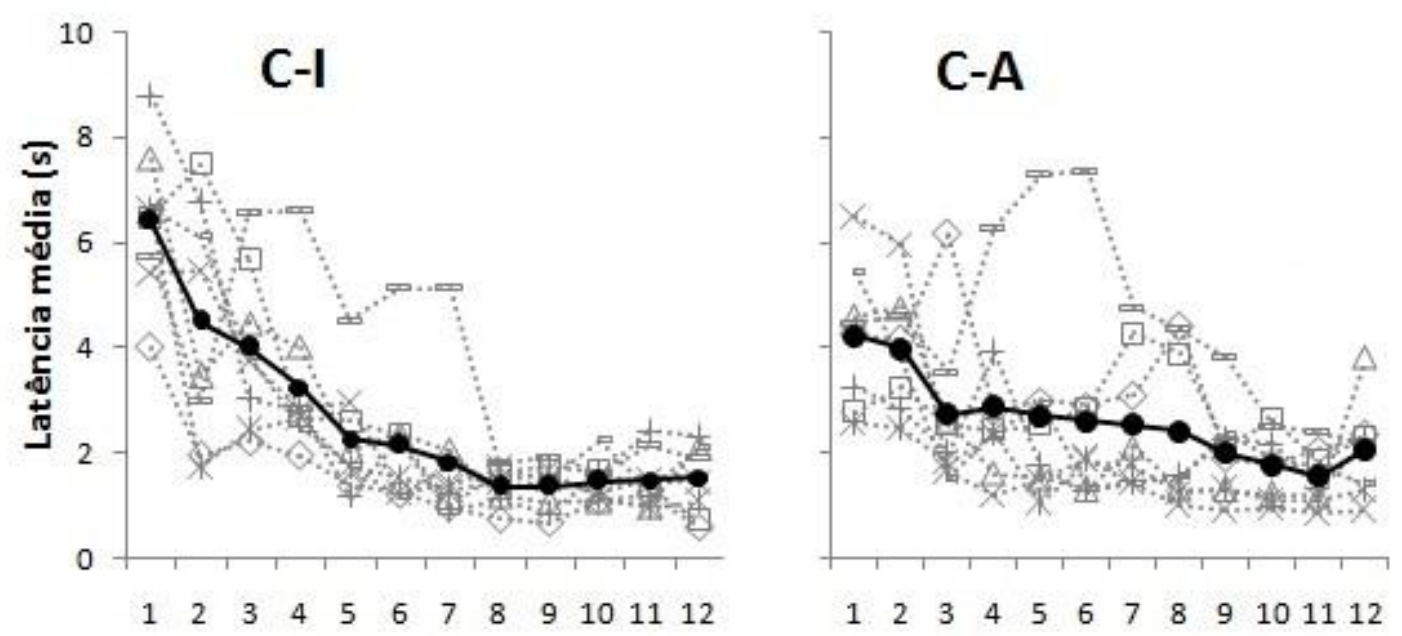

Blocos de 5 tentativas

Figura 5. Latência média, em segundos, da resposta de fuga saltar na sessão Tratamento em sucessivos blocos de cinco tentativas apresentada pelos sujeitos expostos choques controláveis. As linhas pontilhadas correspondem às latências médias dos sujeitos individuais; a linha contínua mostra a latência média do grupo. À esquerda são apresentados os dados do Grupo C-I que posteriormente foi submetido à sessão Teste com a consequência imediata e à direita o Grupo $\mathrm{C}$-A, que posteriormente passou pela sessão Teste com atraso da consequência.

Na Figura 6 estão representados os dados de latência média da resposta de focinhar na sessão Teste emitida pelos animais dos seis grupos aqui testados. Na primeira linha estão plotados os dados dos animais não expostos a choques na sessão de Tratamento (Grupos N-I e N-A), na segunda, dos que puderam controlar esses choques (Grupos C-I e C-A) e na terceira, dos que foram submetidos aos choques incontroláveis (Grupos I-I e I-A). Os grupos de sujeitos que realizaram a sessão Teste com reforço imediato estão localizados na coluna esquerda dessa figura, e os sujeitos expostos ao procedimento com atraso estão do lado direito.

Na média, todos os grupos mostraram latências decrescentes ao longo da sessão Teste, com exceção mais evidente dos animais do Grupo I-A. Contudo, houve um efeito sistemático em função do atraso no reforço negativo entre os componentes das tríades, sendo, no geral, maiores as latências médias dentre os animais expostos ao reforço 
atrasado. Analisando a tríade tratada sem atraso, pode-se verificar que os grupos diferem pouco em função do Tratamento recebido previamente: com exceção de um sujeito do Grupo C-I, os demais mostram latências médias decrescentes à medida que foram sucessivamente expostos ao reforço negativo, terminando a sessão com latências baixas em torno de $2 \mathrm{~s}$ (amplitude entre 1 e $3 \mathrm{~s}$ ). Assim como descrito no experimento anterior, a variabilidade intragrupo, na tríade, foi maior na primeira metade da sessão, de forma que todos os animais tenderam a apresentar respostas de fuga com baixas latências nas tentativas finais.

A tríade exposta ao reforçamento com atraso mostrou desempenho menos homogêneo intragrupo, embora os maiores efeitos tenham sido mostrados pelos sujeitos expostos previamente aos choques incontroláveis. Dentre os sujeitos não expostos a choques, um deles não aprendeu a resposta de fuga e outro apresentou grandes oscilações até o bloco final. Na média, o padrão foi de redução gradual das latências, finalizando a sessão com respostas emitidas com latência em torno de $4 \mathrm{~s}$. O desempenho dos sujeitos que anteriormente exerceram controle sobre os choques não diferiu, no teste, do descrito para os sujeitos não expostos a choques: também um sujeito não aprendeu, os demais variaram bastante na primeira metade da sessão e se aproximaram, no final, a uma média de $4 \mathrm{~s}$. O maior efeito do atraso se deu dentre os sujeitos previamente expostos aos choques incontroláveis: declínio da curva média do grupo bem menos acentuada que a dos demais grupos, com latência média final em torno de 6s e quatro sujeitos com latências finais acima da média do grupo no bloco final, sendo que dois deles não aprenderam fuga. 

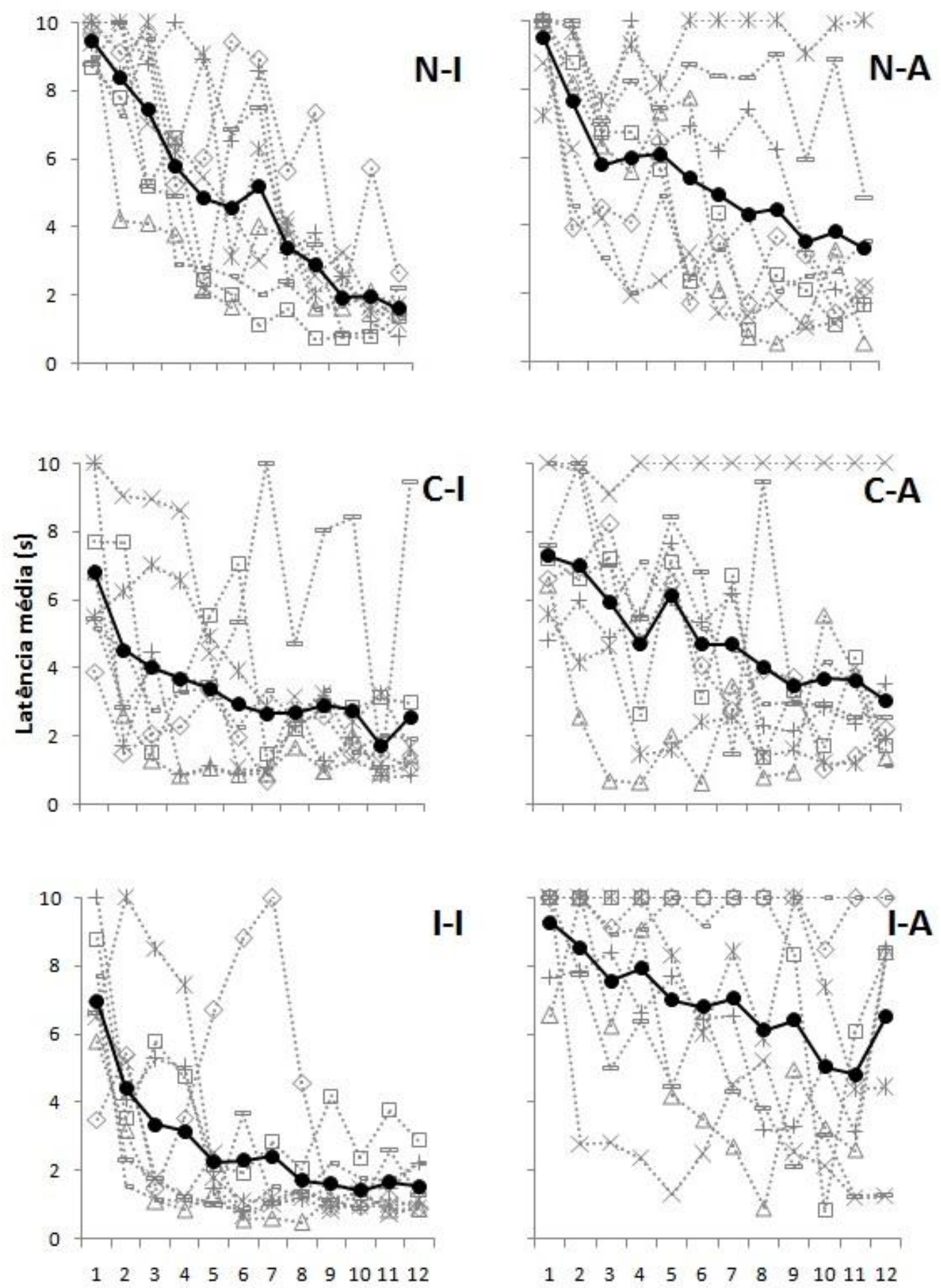

\section{Blocos de 5 tentativas}

Figura 6. Latência média, em segundos, da resposta de fuga focinhar apresentada na sessão Teste, em sucessivos blocos de cinco tentativas, pelos sujeitos expostos a diferentes combinações de Tratamento e Teste, respectivamente: (N-I) nenhum choque / reforçamento imediato; (N-A) nenhum choque / reforçamento atrasado; (C-I) choques controláveis / reforçamento imediato; (C-A) choques controláveis / reforçamento atrasado; (I-I) choques incontroláveis / reforçamento imediato e (I-A) choques incontroláveis / reforçamento atrasado. As linhas pontilhadas correspondem às latências médias dos sujeitos individuais; a linha contínua mostra a latência média do grupo. 
Os padrões de desempenho dos sujeitos na sessão Teste podem ser examinados com maior minúcia na Figura 7, onde cada linha diz respeito aos oito sujeitos de cada grupo, ordenados de modo crescente em função da rapidez da redução das latências. As três primeiras linhas representam os sujeitos que realizaram a sessão Teste com reforço imediato (Grupos N-I, C-I e I-I). De maneira geral, os sujeitos submetidos a essa condição experimental apresentaram uma redução da latência média ao longo dos blocos sucessivos. É necessário, no entanto, salientar o desempenho de dois sujeitos que parecem discrepantes. O Sujeito 6 do Grupo C-I apresentou uma brusca oscilação da latência nos últimos blocos, não apresentando tendência clara de aprendizagem. Quanto a esse sujeito, destaca-se o fato dele já ter apresentado um desempenho destoante na sessão Tratamento, com latências mais elevadas entre todos os sujeitos até o sétimo bloco de tentativas. Já o Sujeito 1 do Grupo I-I, apesar de ter apresentado uma latência relativamente baixa no final da sessão, apresentou latências elevadas nos blocos intermediários.

Ainda na Figura 7, nas três últimas linhas estão os dados dos sujeitos que realizaram a sessão Teste com atraso do reforço. No Grupo N-A, referente aos sujeitos não expostos previamente a choques, percebe-se que o Sujeito 5 não aprendeu a resposta de fuga e o Sujeito 6 apresentou latências sem muita mudança entre blocos iniciais e finais da sessão. Já no Grupo C-A, o Sujeito 4 não mostrou redução da latência ao longo da sessão, enquanto os Sujeitos 2 e 3 mostram oscilações pronunciadas nos blocos finais. No Grupo I-A, apenas dois sujeitos apresentaram padrão claro de aprendizagem de fuga. A tendência de redução da latência ao longo da sessão foi inexistente nos Sujeitos 1 e 8, enquanto que os Sujeitos 3, 7 e 2 apresentam um aumento da latência no último bloco. 


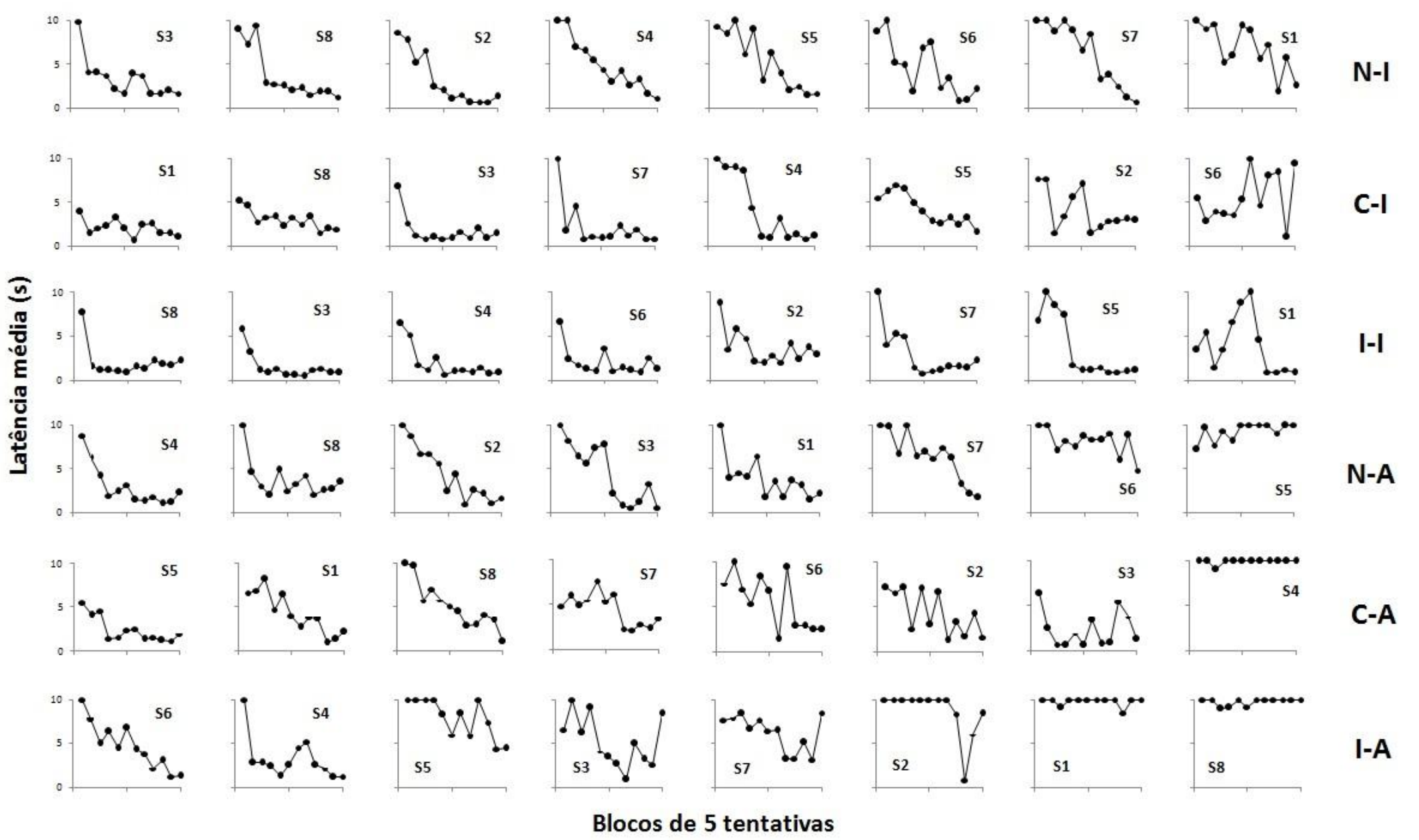

Figura 7. Latência média individual, em segundos, da resposta de fuga focinhar apresentada na sessão Teste em blocos de cinco tentativas. Cada grupo está representado no sentido horizontal, sendo identificado à direita; a ordem dos sujeitos se deu das menores latências à esquerda para as maiores latências à direita. Os sujeitos estão indicados pela notação $\mathrm{S}(n)$, onde $n$ corresponde ao número de identificação do sujeito. 
Na Figura 8 os dados estão reapresentados de modo a possibilitar uma comparação da latência média de cada grupo, onde as linhas pontilhadas representam os grupos nos quais foi empregado o procedimento de fuga sem atraso e as linhas contínuas usadas para os grupos testados com atraso do reforço. Com exceção do Grupo I-A, que no último bloco apresentou um aumento na latência média, todos os grupos apresentaram redução da latência ao longo da sessão. Tal dado é corroborado pela análise estatística que indica diferença significante em relação às sucessivas tentativas $[\mathrm{F}(6,239)=36,59, p<0,001]$

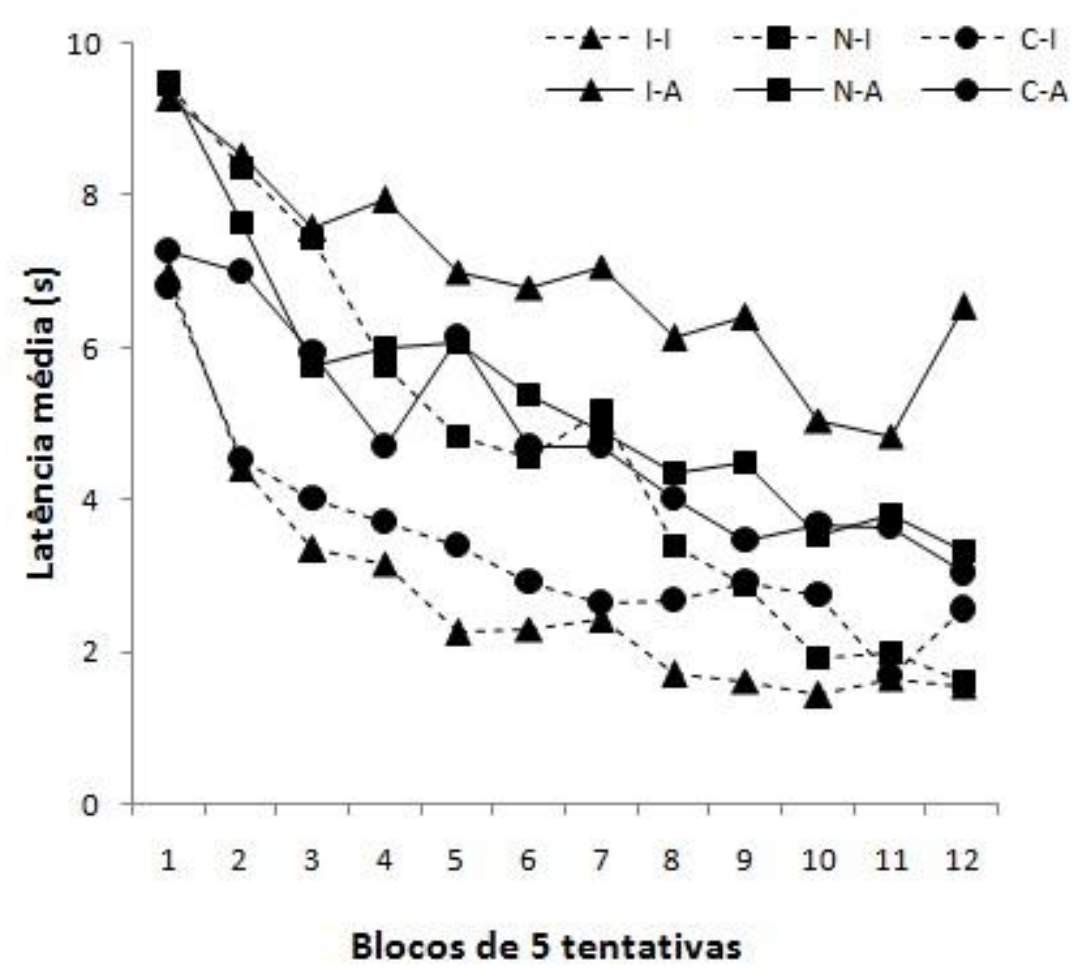

Figura 8. Latência média, em segundos, da resposta de fuga focinhar de cada grupo apresentada na sessão Teste em sucessivos blocos de cinco tentativas, pelos sujeitos expostos a diferentes combinações de Tratamento e Teste, respectivamente: (N-I) nenhum choque / reforçamento imediato; (N-A) nenhum choque / reforçamento atrasado; (C-I) choques controláveis / reforçamento imediato; (C-A) choques controláveis / reforçamento atrasado; (I-I) choques incontroláveis / reforçamento imediato e (I-A) choques incontroláveis / reforçamento atrasado. 
A comparação entre as médias sugere que o atraso do reforço foi uma variável que prejudicou a aprendizagem de fuga de todos os grupos testados. Os três grupos testados com atraso foram aqueles que, no geral, apresentaram maiores latências médias ao longo de toda a sessão comparativamente ao grupo de igual tratamento sem atraso no teste, com exceção apenas do Grupo N-I nos blocos iniciais. A interferência do atraso na aprendizagem de fuga foi especialmente acentuada no Grupo I-A onde a média do grupo não apenas mostrou menor inclinação na queda das latências ao longo dos blocos de tentativas, como apresentou aumento dessa latência no bloco final. A análise estatística indicou diferença significante entre os grupos $[\mathrm{F}(5,42)=5,06, p=0,001]$, sem interação entre tentativa e grupo $[\mathrm{F}(28,239)=1,18, p=0,25]$. A análise de pares dos três últimos blocos de tentativas mostra que o Grupo I-A difere dos grupos que realizaram a sessão teste com reforço imediato (Grupos I-I, N-I e C-I), mas não difere dos Grupos N-A e C-A.

Na Tabela 4 é possível constatar que o atraso real imposto para cada um dos grupos ficou entre 0,55 e $0,59 \mathrm{~s}$, portanto, bastante próximo do atraso programado de 0,6s. A variação do atraso entre os sujeitos de um mesmo grupo também foi de baixa magnitude, sendo que o maior desvio padrão foi de 0,04 para o Grupo C-A. 


\section{Tabela 4}

Média real de atraso imposto aos sujeitos dos grupos NA, CA e IA, disposta em ordem crescente.

\begin{tabular}{|c|c|c|c|c|}
\hline GRUPO & $\begin{array}{c}\text { MÉDIA REAL DE } \\
\text { ATRASO }\end{array}$ & SUJEITO & $\begin{array}{c}\text { MÉDIA DO } \\
\text { GRUPO }\end{array}$ & $\begin{array}{l}\text { DESVIO } \\
\text { PADRÃOO }\end{array}$ \\
\hline \multirow{8}{*}{$\mathrm{N}-\mathrm{A}$} & 0,55 & 7 & \multirow{8}{*}{0,58} & \multirow{8}{*}{0,02} \\
\hline & 0,56 & 5 & & \\
\hline & 0,58 & 8 & & \\
\hline & 0,58 & 4 & & \\
\hline & 0,58 & 2 & & \\
\hline & 0,59 & 6 & & \\
\hline & 0,60 & 1 & & \\
\hline & 0,60 & 3 & & \\
\hline \multirow{8}{*}{ C-A } & 0,47 & 8 & \multirow{8}{*}{0,55} & \multirow{8}{*}{0,04} \\
\hline & 0,51 & 6 & & \\
\hline & 0,53 & 3 & & \\
\hline & 0,54 & 5 & & \\
\hline & 0,57 & 2 & & \\
\hline & 0,58 & 1 & & \\
\hline & 0,58 & 7 & & \\
\hline & 0,60 & 4 & & \\
\hline \multirow{8}{*}{ I-A } & 0,57 & 4 & \multirow{8}{*}{0,59} & \multirow{8}{*}{0,01} \\
\hline & 0,58 & 3 & & \\
\hline & 0,59 & 7 & & \\
\hline & 0,60 & 1 & & \\
\hline & 0,60 & 2 & & \\
\hline & 0,60 & 5 & & \\
\hline & 0,60 & 6 & & \\
\hline & 0,60 & 8 & & \\
\hline
\end{tabular}




\section{DISCUSSÃO}

Dentre os sujeitos não expostos a choques, os que foram testados sem atraso (Grupo N-I) se comportaram de forma semelhante ao grupo equivalente testado no Experimento 1, ou seja, aprenderam a resposta de fuga. Tal dado constitui uma replicação direta (Sidman, 1976) que indica que as variáveis relevantes para o teste em estudo estão com controle experimental adequado.

Neste experimento, entretanto, foi realizado o aumento do valor do atraso do reforço de 0,5s para 0,6s. Essa alteração parece ter sido suficiente para prejudicar a aprendizagem da resposta de focinhar dos sujeitos ingênuos (Grupo N-A). Apesar das latências médias do grupo ainda se mostrarem decrescentes, o que indica aprendizagem de fuga, um dos sujeitos deste grupo não aprendeu a resposta de fuga e outro apresentou uma redução da latência menos drástica ao longo da sessão. Com o atraso de $0,5 \mathrm{~s}$, testado no Experimento 1, isso não foi obtido. Portanto, esse dado sugere que os animais foram sensíveis ao aumento de $0,1 \mathrm{~s}$ no atraso do reforço, e que essa aparentemente pequena diferença na contiguidade da consequência é extremamente relevante no controle do comportamento.

Esse efeito provocado pelo pequeno aumento na duração do atraso do reforço encontra respaldo na literatura. Reilly e Lattal (2004) impuseram um aumento progressivo do atraso do reforço positivo intrasessão sobre a resposta de bicar de pombos e perceberam que quanto maior o valor do atraso, menor era a taxa de resposta. A curva que melhor se ajustou aos dados foi uma curva hiperbólica negativamente acelerada onde inicialmente pequenos os aumentos no valor do atraso afetavam em grande magnitude a taxa de resposta, no entanto, a partir de certo ponto, mesmo com o aumento no atraso a taxa de resposta foi pouco afetada. 
Em outro estudo realizado por Keller (1966), este realizado em contexto aversivo, foi investigado o efeito do atraso do reforço sobre o comportamento de fuga de uma luz intensa apresentado por ratos. Os resultados mostraram que em comparação com a condição com o reforço imediato, atrasos de 1s aumentaram a latência da resposta de fuga. No entanto, a latência sofreu pouca mudança para atrasos maiores, como 2,5 e $10 \mathrm{~s}$.

Nos dados aqui obtidos podemos observar o efeito análogo ao relatado por Reilly e Lattal (2004) e Keller (1966), de que os efeitos podem ser bastante pronunciados em função de um pequeno aumento do atraso do reforço. No entanto, nosso delineamento não permite investigar a partir de qual valor de atraso que os efeitos se tornariam relativamente constantes. Para isso, seria necessário um estudo paramétrico em relação ao atraso do reforço negativo sobre a resposta de focinhar de ratos, algo que parece ter relevância também pela carência de estudos que fazem uma análise experimental do atraso do reforço em contexto aversivo. Essa proposta pode vir a ser executada em outros estudos, mas no momento fugia dos objetivos aqui propostos.

Os dados da sessão Teste dos indivíduos que exerceram controle sobre o choque são fundamentais para responder a questão deste experimento: será que os efeitos do atraso do reforço em sujeitos com história de incontrolabilidade, observados no experimento anterior, se devem de fato a grau de controle sobre os estímulos aversivos ou se devem a mera exposição aos choques? Um dos sujeitos do Grupo C-I não aprendeu a resposta de fuga, mas esse efeito não pode ser relacionado ao atraso do reforço, uma vez que para os sujeitos deste grupo a sessão Teste foi realizada com a consequência imediata. No entanto, esse mesmo sujeito já havia apresentado latências consistentemente acima da média até a metade da sessão Tratamento, o que pode levar à conclusão de que o resultado seja decorrente de características individuais do sujeito, 
como por exemplo, uma maior suscetibilidade ao estímulo aversivo, e não necessariamente às condições experimentais, uma vez que todos os outros sujeitos do grupo aprenderam fuga.

O desempenho dos sujeitos do Grupo C-A, que possuíam história de controle sobre o estímulo aversivo e foram testados com atrasos do reforço negativo, também foi afetado. Neste grupo, apesar de todos os sujeitos terem aprendido fuga, a queda da latência média do grupo foi menos acentuada que a do grupo testado sem atraso. Portanto, nossos dados sugerem que o atraso de 0,6 s do reforço negativo, nas condições aqui testadas, interferiu, ao menos levemente, na aquisição de um novo operante em sujeitos com história de controle sobre estímulos aversivos.

A maior diferença entre grupos com o mesmo procedimento na sessão Tratamento foi em relação aos sujeitos expostos previamente a choques incontroláveis. O Grupo I-I que foi testado com a consequência imediata apresentou as menores latências médias ao longo da sessão entre todos os grupos deste experimento, já o Grupo I-A apresentou as maiores latências médias. Esse dado é um indício de que uma história de incontrolabilidade não foi suficiente para a ocorrência do desamparo aprendido, sendo necessário que além dessa história, houvesse um atraso entre a resposta e a consequência. Esse dado dá suporte para a hipótese de Santos et al. (2011) de que a incontrolabilidade torna os organismos mais sensíveis à relações de contiguidade. Isso pode ser sustentado pelo fato de que os sujeitos que foram testados com o reforço imediato apresentaram uma redução da latência mais pronunciada em relação àqueles que realizaram o teste com atraso do reforço.

Apesar dos indícios que a comparação entre os Grupos I-I e I-A fornecem para a influência do atraso do reforço negativo em função de uma história de 
incontrolabilidade sobre estímulos aversivos, os dados deste experimento possuem limitações para estender essas conclusões para a ocorrência do desamparo aprendido. A ocorrência do efeito de desamparo aprendido, entendido como dificuldade de aprendizagem, pode ser constatada a partir de uma diferença significante entre o desempenho de sujeitos que não foram expostos ao estímulo aversivo e que tiveram controle sobre o mesmo em comparação com os sujeitos com história de incontrolabilidade. No entanto, apesar de visualmente o Grupo I-A ter apresentado um padrão de aprendizagem de fuga menos eficiente (latências gerais mais altas e as finais aumentando) do que os Grupos N-A e C-A, estatisticamente essa diferença não foi significante.

Uma das fontes para esta limitação está justamente no aumento do atraso do reforço de 0,5 para 0,6 s que afetou a aprendizagem de fuga dos sujeitos dos Grupos $\mathrm{N}$ A e C-A. Além disso, a não aprendizagem de um dos sujeitos do Grupo N-I, foi suficiente para aumentar a latência média deste grupo. Como decorrência, esses grupos apresentaram latências intermediárias entre os Grupos I-I e I-A, inviabilizando uma clara distinção estatística entre os grupos de acordo com o tipo de tratamento.

A falta de diferença significante entre o Grupo I-A e N-A traz outra questão a ser analisada. No estudo de Yano e Hunziker (2000) tanto os sujeitos do grupo ingênuo como os com história de incontrolabilidade, quando testados também foram, supostamente, expostos ao atraso inerente ao equipamento eletromecânico. Mas diferentemente dos dados aqui obtidos, Yano e Hunziker (2000) encontraram uma evidente diferença entre os dois grupos. Uma possível explicação pode ser a diferença no tempo de exposição aos choques incontroláveis. Yano e Hunziker (2000) utilizaram o procedimento de expor os sujeitos a choques incontroláveis de duração fixa de 10s, e neste experimento foi utilizado o procedimento acoplado, que comparativamente expõe 
cada sujeito a choques de duração que em média vai sendo reduzida ao longo da sessão (devido à aprendizagem de fuga dos sujeitos do grupo que controla o choque). Consequentemente, os sujeitos do estudo de Yano e Hunziker (2000) foram mais expostos à incontrolabilidade, o que pode ter produzido dificuldade de aprendizagem mais acentuada.

Como o aumento do valor do atraso do reforço empregado neste experimento para tornar mais evidente o efeito nos grupos com história de incontrolabilidade se mostrou inadequado, tendo em vista o aumento latência média dos outros grupos, se faz necessário um exame do próprio procedimento. Lattal (2010) afirma que o procedimento de atraso do reforço no qual se permite o responder durante o período de atraso, sem que o mesmo seja reiniciado, se configura efetivamente como um procedimento de atraso variável. Apesar do atraso nominal ser especificado pelo experimentador, o atraso real para o sujeito pode variar. Ou seja, alguns sujeitos podem ser expostos a atrasos menores, enquanto que outros são expostos ao atraso programado, conforme apresentado na Tabela 4.

Considerando a característica de possibilidade de variação no valor do atraso, uma alternativa plausível seria o próprio experimentador definir atrasos variáveis de modo a expor o organismo tanto a valores baixos que possibilitem a aquisição da resposta, quanto a valores mais altos que tornem evidente o efeito do atraso no desempenho dos sujeitos. Com isso, de certa maneira se garante que alguns sujeitos necessariamente serão expostos a atrasos de menor magnitude, o que pode facilitar a aquisição da resposta de fuga e evitar o problema anteriormente analisado de aumento da latência dos sujeitos não expostos a choques e que exerceram controle sobre o choque. Sendo assim, o Experimento 3, apresentado a seguir, foi planejado com o atraso do reforço negativo variável entre 0,45 e $0,75 \mathrm{~s}$, mantendo o atraso médio de $0,6 \mathrm{~s}$. 


\section{EXPERIMENTO 3}

\section{MÉTODO}

\section{Objetivo}

Verificar se ratos tratados com choques controláveis, incontroláveis ou nenhum choque, e posteriormente submetidos à reforçamento negativo (fuga) com um procedimento de atraso variável do reforço de $0,6 \mathrm{~s}(0,45$ - $0,75 \mathrm{~s})$ apresentam desempenho diferencial em relação a sujeitos submetidos ao procedimento de fuga sem atraso do reforço.

\section{Sujeitos}

Foram utilizados 48 ratos albinos da linhagem Wistar com as mesmas características, e alojados sob as mesmas condições, dos sujeitos dos experimentos anteriores.

\section{Equipamentos}

Foram utilizados os mesmos equipamentos do Experimento 2.

\section{Procedimento}

O procedimento deste experimento se assemelhou ao do Experimento 2, com a única diferença de que nos grupos testados com atraso sob reforçamento negativo, o 
intervalo entre resposta e término do choque foi variável a cada tentativa, com valores entre 0,45 e $0,75 \mathrm{~s}$. A Tabela 5 apresenta resumidamente esse procedimento.

\section{Tabela 5}

Principais características do procedimento adotado no Experimento 3

\begin{tabular}{|c|c|c|c|}
\hline FASES & TRATAMENTO & \multicolumn{2}{|c|}{$\begin{array}{c}\text { TESTE } \\
\text { (RESPOSTA DE FOCINHAR) }\end{array}$} \\
\hline C-I & $\begin{array}{l}\text { - } 60 \text { choques controláveis } \\
\text { (fuga) }\end{array}$ & \multirow{6}{*}{$\begin{array}{l}\text { - } 60 \text { choques } \\
\text { controláveis (fuga) } \\
\text { - VT 60s } \\
\text { - } 10 \text { s máximos } \\
\text { - } 1 \mathrm{~mA}\end{array}$} & - Reforçamento imediato \\
\hline $\mathrm{C}-\mathrm{A}$ & $\begin{array}{l}\text { - 10s máximos } \\
\text { - 1mA } \\
\text { - resposta de saltar }\end{array}$ & & $\begin{array}{l}\text { - Reforçamento atrasado } \\
\text { variável }(0,45-0,75 \mathrm{~s})\end{array}$ \\
\hline I-I & \multirow{2}{*}{$\begin{array}{l}\text { - } 60 \text { choques } \\
\text { incontroláveis } \\
\text { - Acoplado } \\
\text { - 1mA }\end{array}$} & & - Reforçamento imediato \\
\hline $\mathrm{I}-\mathrm{A}$ & & & $\begin{array}{l}\text { - Reforçamento atrasado } \\
\text { variável }(0,45-0,75 \mathrm{~s})\end{array}$ \\
\hline N-I & \multirow{2}{*}{$\begin{array}{l}\text { - Permanência na caixa } \\
\text { experimental }\end{array}$} & & - Reforçamento imediato \\
\hline $\mathrm{N}-\mathrm{A}$ & & & $\begin{array}{r}\text { - Reforçamento atrasado } \\
\text { variável }(0,45-0,75 \mathrm{~s})\end{array}$ \\
\hline
\end{tabular}

\section{Análise de dados}

Foram utilizadas as mesmas medidas e testes estatísticos dos experimentos anteriores. 


\section{RESULTADOS}

Os dados das latências médias da resposta de fuga serão apresentados na ordem de realização das fases do experimento (Tratamento seguido de Teste). Os dados individuais estão representados por linhas pontilhadas e a média do grupo representada pela linha contínua. Na Figura 9 estão as latências médias da resposta de saltar da sessão Tratamento dos sujeitos dos grupos expostos a choques controláveis. O gráfico à esquerda diz respeito ao Grupo C-I, que posteriormente foi submetido à sessão Teste com a consequência imediata, e à direita ao Grupo C-A, exposto na sessão seguinte ao procedimento de fuga com atraso da consequência.

Em ambos os grupos as latências sucessivas configuram um tendência decrescente, indício de que todos os sujeitos tiveram controle sobre o encerramento do choque. Com exceção de dois sujeitos do Grupo C-I e um sujeito do Grupo C-A, que apresentaram uma redução mais lenta e com bruscas oscilações, os demais sujeitos apresentaram um padrão relativamente uniforme. Se comparadas as latências médias de cada grupo, percebe-se que são muito semelhantes entre si, com latência na faixa de $6 \mathrm{~s}$ nos blocos iniciais que se reduziram gradualmente até aproximadamente $2 \mathrm{~s}$ nos blocos finais. 

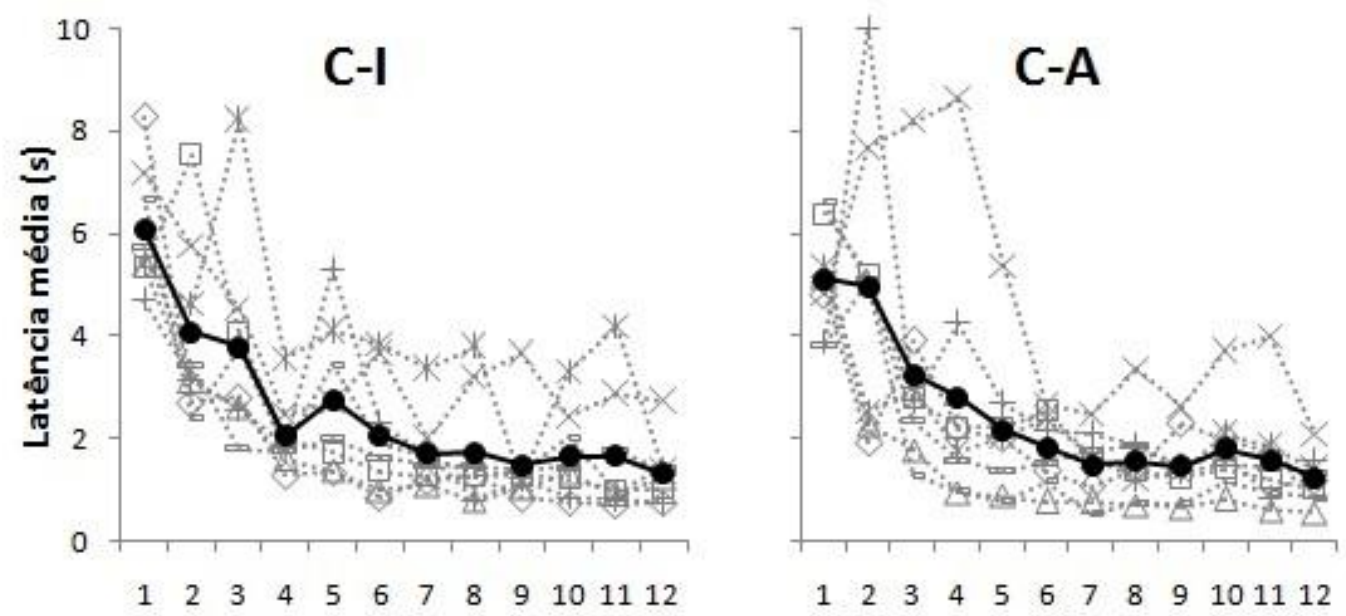

Blocos de 5 tentativas

Figura 9. Latência média, em segundos, da resposta de fuga saltar na sessão Tratamento em sucessivos blocos de cinco tentativas apresentada pelos sujeitos expostos choques controláveis. As linhas pontilhadas correspondem às latências médias dos sujeitos individuais; a linha contínua mostra a latência média do grupo. À esquerda são apresentados os dados do Grupo C-I que posteriormente foi submetido à sessão Teste com a consequência imediata e à direita o Grupo C-A, que posteriormente passou pela sessão Teste com atraso da consequência.

Na Figura 10 estão representados os dados das latências médias da resposta de focinhar emitidas na sessão Teste pelos sujeitos de todos os grupos. Na primeira linha estão representados os grupos não expostos a choques (Grupos N-I e N-A), na segunda linha os grupos controláveis (Grupos C-I e C-A) e na terceira, os grupos incontroláveis (Grupos I-I e I-A). Os grupos que realizaram o teste com reforço imediato estão localizados na coluna esquerda da figura e os grupos com atraso estão do lado direito. 

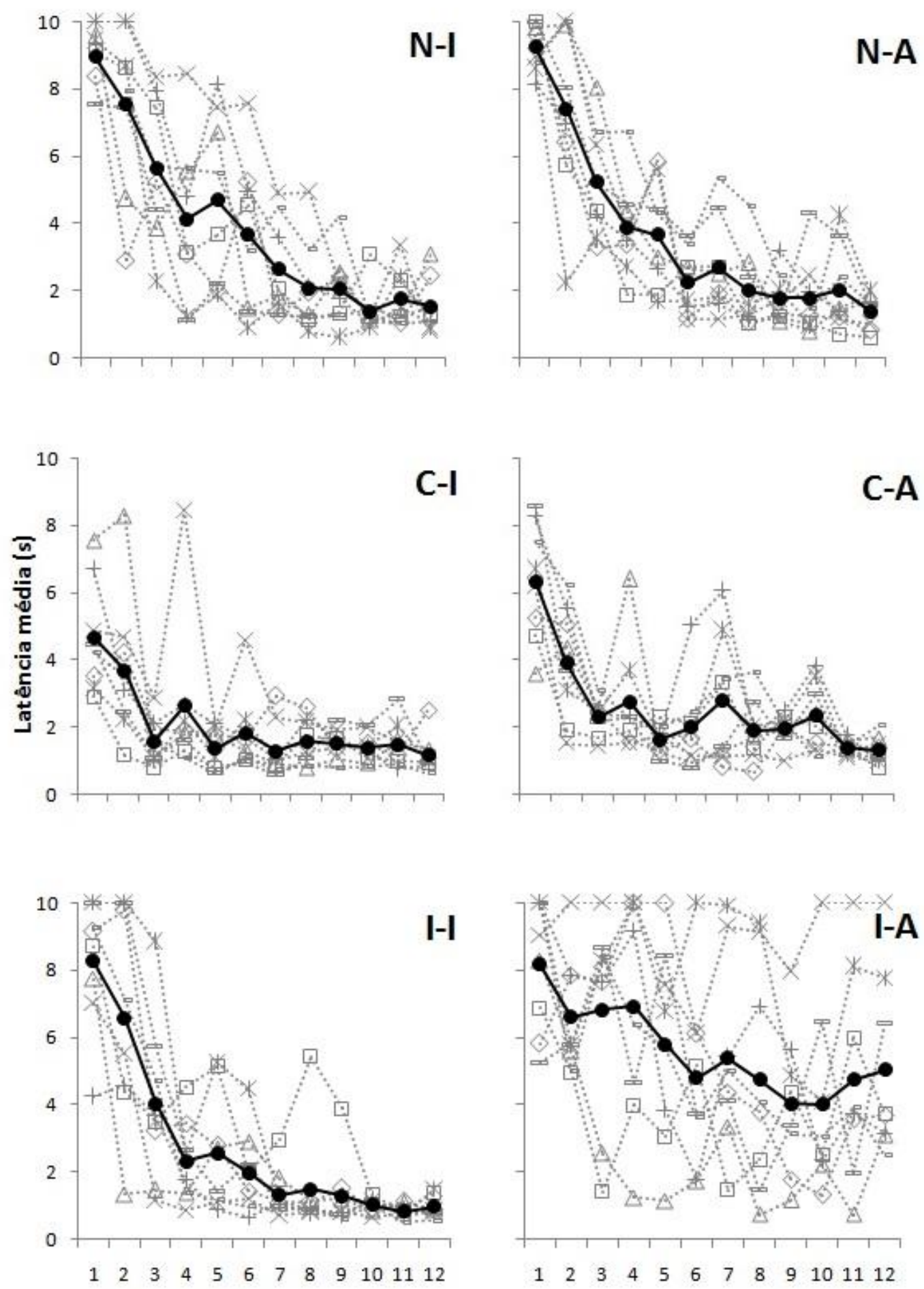

\section{Blocos de 5 tentativas}

Figura 10. Latência média, em segundos, da resposta de fuga focinhar apresentada na sessão Teste, em sucessivos blocos de cinco tentativas, pelos sujeitos expostos a diferentes combinações de Tratamento e Teste, respectivamente: (N-I) nenhum choque / reforçamento imediato; (N-A) nenhum choque / reforçamento atrasado; (C-I) choques controláveis / reforçamento imediato; (C-A) choques controláveis / reforçamento atrasado; (I-I) choques incontroláveis / reforçamento imediato e (I-A) choques incontroláveis / reforçamento atrasado. As linhas pontilhadas correspondem às latências médias dos sujeitos individuais; a linha contínua mostra a latência média do grupo. 
Os sujeitos não expostos a choques (Grupos N-I e N-A), independentemente da imposição ou não de atrasos para a resposta de fuga, apresentaram uma clara redução da latência ao longo dos blocos. Visualmente, não é possível perceber que haja algum sujeito com um desempenho desviante da média do seu respectivo grupo. Além disso, as latências médias desses dois grupos são bastante semelhantes entre si, com latências iniciais próximas de 9s sendo reduzidas até 2s no último bloco.

Com relação aos sujeitos dos Grupos C-I e C-A, expostos previamente a choques controláveis, percebe-se também redução da latência média ao longo da sessão. No entanto, estes grupos apresentam latências nos blocos iniciais mais baixas. O Grupo C-I, no primeiro bloco, apresenta uma latência média de aproximadamente 5s e o Grupo C-A de $6 \mathrm{~s}$, muito embora, a latência nos blocos finais fique em torno de $2 \mathrm{~s}$, em ambos os grupos. De forma geral, os dois grupos não apresentam diferenças significantes entre si.

Já os Grupos I-I e I-A são aqueles que, apesar de terem recebido mesmo tipo de Tratamento (choques incontroláveis), diferem entre si de forma mais evidente. Enquanto que o Grupo I-I mostra padrão de redução sistemática da latência ao longo dos sucessivos blocos, o Grupo I-A, além de apresentar enorme variação intragrupo, mostra elevação da latência média nos últimos três blocos de tentativas.

Um exame do desempenho individual pode ser feito a partir da Figura 11, onde cada uma das linhas diz respeito a um grupo, estando os sujeitos apresentados de forma crescente em função da redução mais rápida da latência ao longo da sessão. 

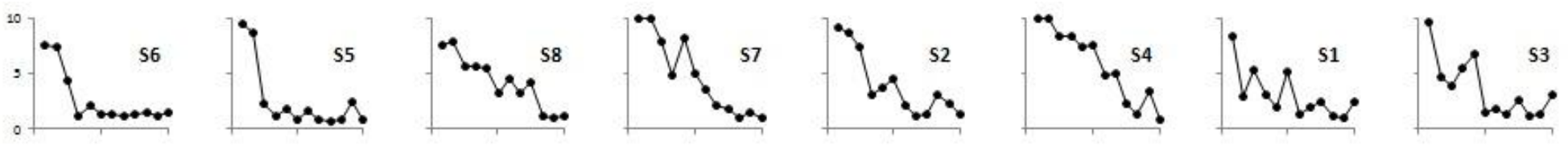

$\mathrm{N}-\mathrm{I}$
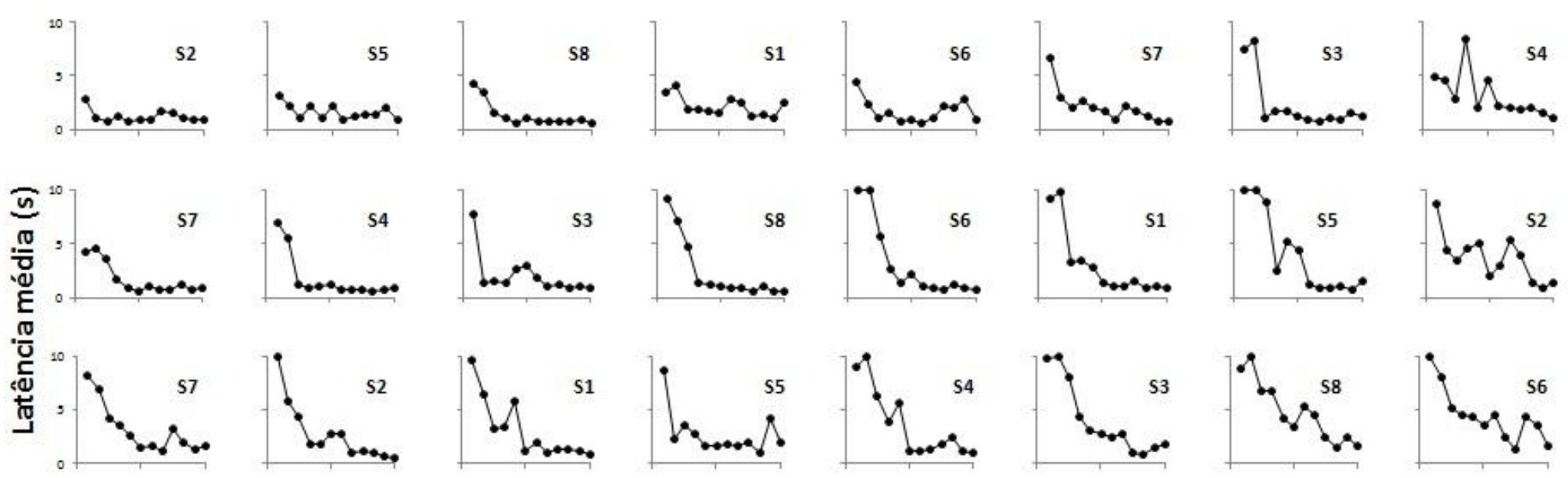

I-I
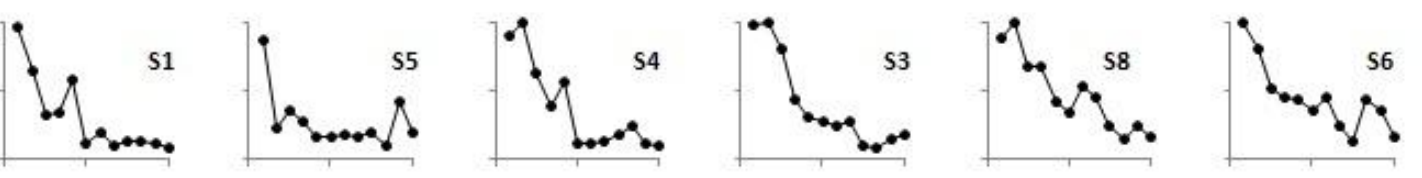

N-A
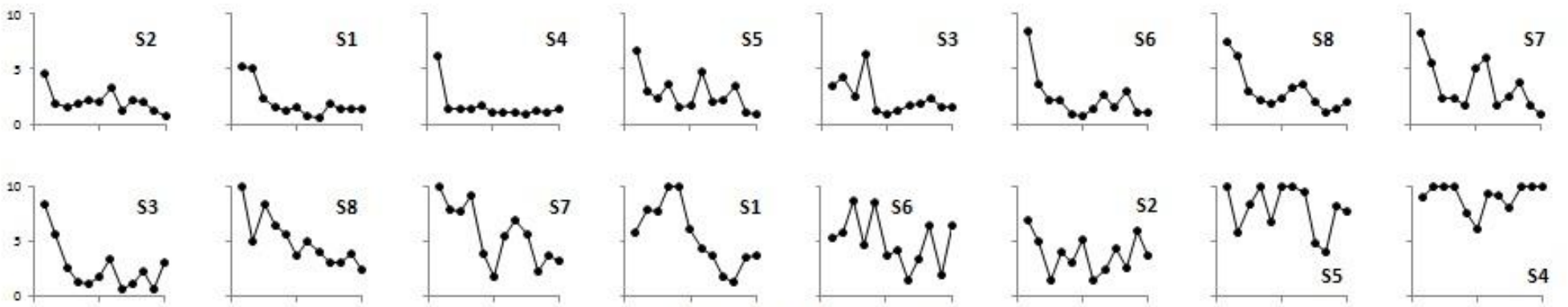

I-A

Blocos de 5 tentativas

Figura 11. Latência média individual, em segundos, da resposta de fuga focinhar apresentada na sessão Teste em blocos de cinco tentativas. Cada grupo está representado no sentido horizontal, sendo identificado à direita; a ordem dos sujeitos se deu das menores latências à esquerda para as maiores latências à direita. Os sujeitos estão indicados pela notação $\mathrm{S}(n)$, onde $n$ corresponde ao número de identificação do sujeito. 
Os três primeiros grupos apresentados na Figura 11 correspondem aqueles que realizaram a sessão Teste com o reforçamento imediato para a resposta de fuga focinhar (Grupos N-I, C-I e I-I). Independente do tipo de tratamento recebido, todos os sujeitos destes grupos apresentaram curva decrescente das latências ao longo dos blocos sucessivos. O mesmo pode ser observado em relação aos sujeitos dos Grupos N-A e CA, que mesmo com o procedimento de fuga impondo atrasos variáveis da consequência, apresentam padrão de aprendizagem típico de fuga. Já um exame dos sujeitos do Grupo I-A indica que o padrão de aprendizagem foi menos evidente, principalmente para os Sujeitos 6, 2, 5 e 4 .

Na Figura 12 é apresentada uma comparação entre os grupos a partir da latência média da resposta de fuga, onde as linhas pontilhadas representam os grupos expostos ao procedimento de fuga com a consequência imediata e as linhas contínuas usadas para os grupos testados com atraso da consequência. Observa-se que há diferenças quanto às latências iniciais para cada um dos grupos, onde os grupos expostos a choques controláveis (Grupos C-I e C-A) apresentam as latências mais baixas no início da sessão de teste, na faixa de $5 \mathrm{~s}$ e $6 \mathrm{~s}$, respectivamente. Os demais grupos apresentam latências iniciais mais elevadas, com valores entre $8 \mathrm{~s}$ e $9 \mathrm{~s}$. Com o decorrer da sessão, as latências de todos os grupos, exceto do Grupo I-A, convergiram para uma média final em torno de 2s. Apesar da redução da latência média do Grupo I-A até o nono bloco, nos últimos três blocos houve um ligeiro aumento, de modo que ao final, a latência da resposta ficou aproximadamente em torno de $5 \mathrm{~s}$, um patamar consideravelmente superior aos demais grupos. 


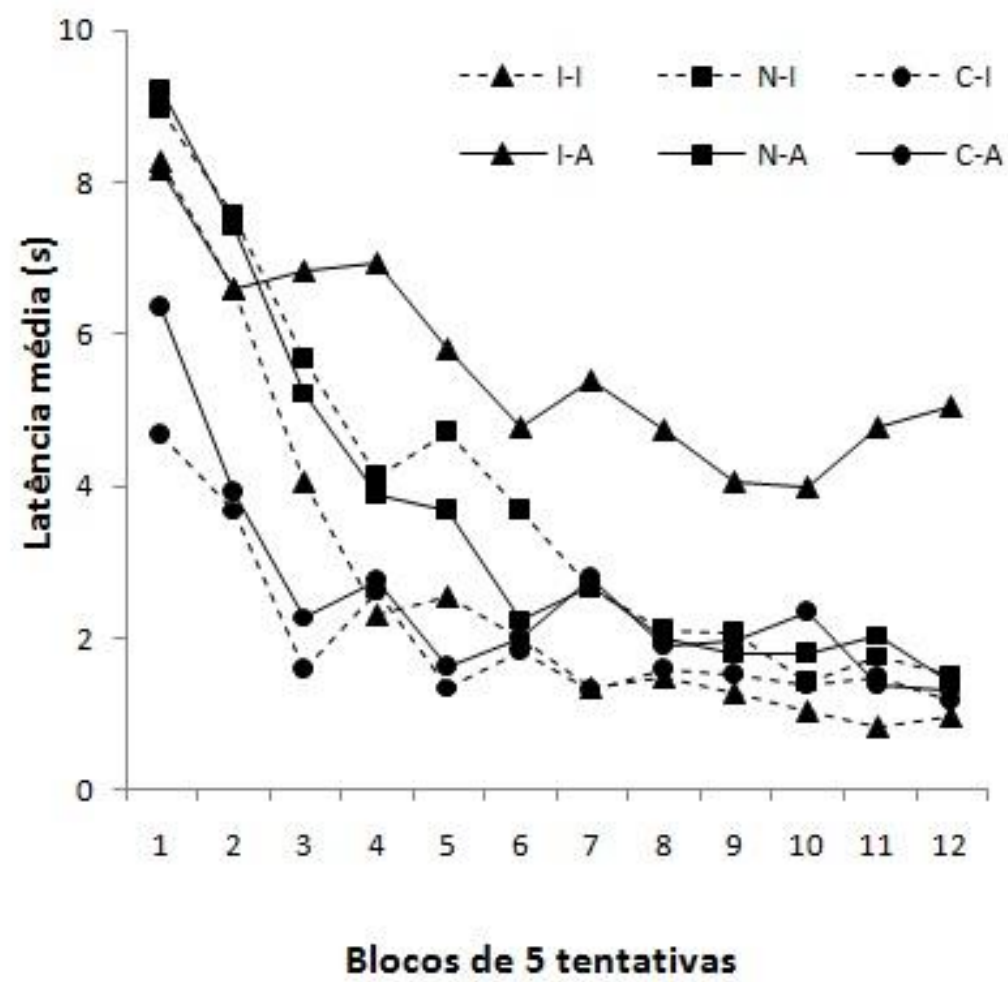

Figura 12. Latência média, em segundos, da resposta de fuga focinhar de cada grupo apresentada na sessão Teste em sucessivos blocos de cinco tentativas, pelos sujeitos expostos a diferentes combinações de Tratamento e Teste, respectivamente: (N-I) nenhum choque / reforçamento imediato; (N-A) nenhum choque / reforçamento atrasado; (C-I) choques controláveis / reforçamento imediato; (C-A) choques controláveis / reforçamento atrasado; (I-I) choques incontroláveis / reforçamento imediato e (I-A) choques incontroláveis / reforçamento atrasado.

A análise estatística da latência média dos grupos da Figura 12 indicou diferença significante em relação às tentativas $[\mathrm{F}(6,264)=77,58, p<0,001]$, ou seja, a latência média foi sendo alterada ao longo da sessão, o que pode ser interpretado como aprendizagem. Foi obtida diferença significante também em relação aos diferentes grupos $[\mathrm{F}(5,42)=10,45, p<0,001]$ e interação do tratamento com as tentativas $[\mathrm{F}(31,264)=3,05, p<0,001]$. Com exceção do oitavo bloco, o teste post hoc indicou diferença significante em todos os blocos de tentativas e a análise por pares indicou que, a partir do nono bloco até o final da sessão, o Grupo I-A diferiu significantemente do Grupo I-I, e no último bloco o Grupo I-A diferiu de todos os demais grupos. 
Os valores reais de atraso para cada sujeito e a média de seu respectivo grupo estão apresentados na Tabela 6. Como ocorreu nos experimentos anteriores, a média de atraso para todos os grupos ficou muito próxima do atraso programado, $0,6 \mathrm{~s}$ na média. Houve baixa dispersão dos valores apresentados pelos indivíduos em relação à média de seu grupo, com desvios padrão que ficaram entre 0,02 e 0,03 .

\section{Tabela 6}

Média real de atraso imposto aos sujeitos dos grupos NA, CA e IA, disposta em ordem crescente.

\begin{tabular}{|c|c|c|c|c|}
\hline GRUPO & $\begin{array}{c}\text { MÉDIA REAL DE } \\
\text { ATRASO }\end{array}$ & SUJEITO & $\begin{array}{c}\text { MÉDIA DO } \\
\text { GRUPO }\end{array}$ & $\begin{array}{l}\text { DESVIO } \\
\text { PADRÃO }\end{array}$ \\
\hline \multirow{8}{*}{$\mathrm{N}-\mathrm{A}$} & 0,55 & 4 & \multirow{8}{*}{0,59} & \multirow{8}{*}{0,02} \\
\hline & 0,56 & 1 & & \\
\hline & 0,60 & 2 & & \\
\hline & 0,60 & 8 & & \\
\hline & 0,60 & 3 & & \\
\hline & 0,60 & 7 & & \\
\hline & 0,61 & 5 & & \\
\hline & 0,61 & 6 & & \\
\hline \multirow{8}{*}{ C-A } & 0,51 & 7 & \multirow{8}{*}{0,55} & \multirow{8}{*}{0,03} \\
\hline & 0,53 & 6 & & \\
\hline & 0,54 & 3 & & \\
\hline & 0,55 & 4 & & \\
\hline & 0,58 & 5 & & \\
\hline & 0,58 & 8 & & \\
\hline & 0,58 & 1 & & \\
\hline & 0,58 & 2 & & \\
\hline \multirow{8}{*}{ I-A } & 0,54 & 1 & \multirow{8}{*}{0,57} & \multirow{8}{*}{0,02} \\
\hline & 0,55 & 6 & & \\
\hline & 0,55 & 2 & & \\
\hline & 0,57 & 8 & & \\
\hline & 0,57 & 3 & & \\
\hline & 0,60 & 7 & & \\
\hline & 0,60 & 5 & & \\
\hline & 0,61 & 4 & & \\
\hline
\end{tabular}




\section{DISCUSSÃO}

Na sessão Teste, as latências médias dos grupos N-I, N-A, C-I e C-A foram bastante semelhantes entre si. Esses quatro grupos apresentaram redução da latência ao longo dos blocos de tentativas, chegando a ficar em torno de 2 s no final da sessão. A partir desses dados é possível supor que a utilização de atrasos variáveis do reforço pouco afetou a aquisição do comportamento de fuga de organismos que não haviam tido contato com a estimulação aversiva ou que tiveram controle sobre sua ocorrência. Esses resultados constituem uma contribuição para a literatura acerca do desamparo aprendido, tendo em vista que os estudos que investigaram o efeito do atraso do reforço

o fizeram somente comparando sujeitos ingênuos e sujeitos com história de incontrolabilidade, mas não utilizando a tríade completa (Maier \& Testa, 1975; Minor, Jackson \& Maier, 1984).

O uso da tríade ressalta que o efeito do atraso não ocorre por si só, mas ele interage com os efeitos da incontrolabilidade: ele foi diferencial, gerando efeito mais acentuado no comportamento apenas dos animais previamente expostos aos choques incontroláveis. O efeito de dificultar a aprendizagem da resposta de fuga não ocorreu com os sujeitos do Grupo I-I testados com a consequência imediata à resposta. Apesar da exposição à incontrolabilidade, os sujeitos deste grupo apresentaram um padrão equivalente aos grupos N-I, N-A, C-I e C-A. Somente os sujeitos do Grupo I-A que apresentaram dificuldade em aprender a resposta de focinhar, o que indica que apenas a história de incontrolabilidade não foi suficiente para a ocorrência do desamparo aprendido, sendo necessária a exposição do sujeito a uma condição no qual haja menor contiguidade entre resposta e consequência. 
Esses resultados dão sustentação para a hipótese formulada por Hunziker e Gehm (2010) e Santos et al. (2011) e que orientou este estudo. Uma história de incontrolabilidade sobre estímulos aversivos tornou os sujeitos mais sensíveis a relações de contiguidade entre resposta e consequência, o que é evidenciado por maiores latências apresentadas pelos sujeitos com história de incontrolabilidade submetidos ao procedimento de fuga com atraso do reforço negativo, onde a consequência ocorria de forma menos contígua em relação à resposta.

Outra previsão apresentada por Hunziker e Gehm (2010) foi confirmada. A depender das condições dispostas no teste de fuga, um sujeito com história de incontrolabilidade pode apresentar um desempenho tão acurado quanto o desempenho de sujeitos ingênuos. Quanto a isso, os sujeitos do Grupo I-I apresentaram latências médias nos últimos seis blocos de tentativas comparáveis à dos sujeitos não expostos a choques. Se a história de incontrolabilidade aumenta o grau de controle exercido pela contiguidade entre resposta e consequência, é previsto pela hipótese de Hunziker e Gehm (2010) que os sujeitos do Grupo I-I quando testados com a consequência imediata, aprendam bem a resposta de fuga.

O uso de atrasos variáveis foi mais adequado em comparação com os atrasos fixos utilizados nos experimentos anteriores, pois os atrasos variáveis nos valores empregados pouco afetaram o desempenho dos sujeitos expostos a choques controláveis ou nenhum choque, possibilitando uma clara distinção do efeito do atraso em relação aos sujeitos com história de incontrolabilidade. No entanto, essa parece ser uma variável a ser investigada. Além de estudos paramétricos em relação à duração do atraso do reforço, se fazem necessárias investigações adicionais quanto à forma de apresentação do atraso do reforço (fixo ou variável, com ou sem sinalização), pois cada procedimento 
pode alterar também a previsibilidade da consequência, o que pode ter implicações para a ocorrência do desamparo aprendido.

De maneira geral, podemos concluir que foram obtidas as condições experimentais adequadas para avaliar o efeito do atraso do reforço negativo na produção do desamparo aprendido. Os dados obtidos parecem confirmar a hipótese de aumento do controle pela contiguidade formulada por Hunziker e Gehm (2010) e Santos et al. (2011) e se contrapõem as hipótese tradicionais. A seguir será apresentada uma discussão geral para examinar as implicações dos dados obtidos nos três experimentos para a análise teórica sobre o efeito comportamental da exposição a eventos aversivos incontroláveis. 


\section{DISCUSSÃO GERAL}

Os dados experimentais aqui obtidos podem trazer contribuições para confrontar as diferentes hipóteses explicativas para a ocorrência do efeito comportamental denominado desamparo aprendido e avaliar o quanto elas são suficientes para descrever os dados experimentais obtidos tanto nesta pesquisa, quanto os dados disponíveis na literatura. Possibilitam também avaliar a adequação da hipótese alternativa proposta por Hunziker e Gehm (2010) e Santos et al. (2011), nomeada aqui como hipótese da contiguidade potencializada, para explicar esses mesmos dados.

Para iniciar essa análise, um aspecto importante é distinguir o fenômeno das hipóteses que buscam explicá-1o ${ }^{1}$. Quanto ao fenômeno, há a concordância de que se refere a um efeito comportamental objetivamente mensurável: dificuldade de aprendizagem, geralmente de comportamentos de fuga, decorrente de uma história de exposição a eventos aversivos incontroláveis. O processo comportamental responsável por esse efeito (sua explicação ou interpretação teórica) é que tem sido objeto de diferentes compreensões.

Conforme abordado na Introdução desta tese, dentre as hipóteses existentes na literatura, as mais destacadas são a hipótese do desamparo aprendido (Overmier \& Seligman, 1967; Maier \& Seligman, 1976; Peterson et al., 1993) e da inatividade aprendida (Glazer \& Weiss, 1976a). Mais recentemente, foi proposta a hipótese da contiguidade potencializada (Hunziker \& Gehm, 2010; Santos et al., 2011).

\footnotetext{
${ }^{1}$ Já foi objeto de crítica o fato de que uma das hipóteses explicativas adotou o mesmo nome que o fenômeno em estudo, estratégia essa que pode ter contribuído para diluir a distinção entre fenômeno e sua explicação (Hunziker, 1982; 2003).
} 
A hipótese do desamparo aprendido propõe que a exposição incontrolabilidade faz com que o organismo aprenda que não há relação entre suas respostas e as alterações no ambiente que se seguem a elas, aprendizagem essa que posteriormente interfere com a aprendizagem oposta de uma nova relação operante (Maier \& Seligman, 1976; Overmier \& Seligman, 1967; Petreson et al., 1993). Diferentemente, a hipótese da inatividade aprendida propõe que frente aos choques incontroláveis o sujeito aprende a ficar "inativo" (em função de punição acidental da atividade e reforçamento negativo acidental da inatividade), comportamento que competiria posteriormente com a emissão de resposta de fuga que envolvesse grande movimentação corporal (Glazer \& Weiss, 1976a). Por fim, a hipótese da contiguidade potencializada, propõe que a exposição à incontrolabilidade sobre estímulos aversivos tornaria o organismo mais sensível a outras relações de controle, além da consequenciação, como por exemplo, o controle por relações de contiguidade entre resposta e a consequência reforçadora negativa, variável investigada neste trabalho (Hunziker \& Gehm, 2010; Santos et al., 2011).

Para confrontá-las é preciso que sejam examinadas algumas questões. Em que aspectos elas se assemelham e em quais se diferenciam? As diferenças entre elas são testáveis? Os dados experimentais disponíveis na literatura (e no presente estudo) permitem que essas diferenças sejam confrontadas, visando maior clareza na interpretação desse efeito comportamental, em particular, e na análise do comportamento como um todo?

Um ponto de confluência entre as hipóteses é que o efeito de dificuldade de aprendizagem observado decorre de alguma aprendizagem prévia. A hipótese do desamparo aprendido assume que a exposição à incontrolabilidade cria condições para a aprendizagem de que não há relação entre as respostas apresentadas pelo organismo e as consequências por ela produzidas. Já a hipótese da inatividade aprendida assume que a 
exposição à incontrolabilidade faz com que o organismo aprenda a ficar inativo ou imóvel. A hipótese da contiguidade potencializada assume que o organismo aprende a ficar mais sensível às relações de contiguidade entre as respostas e as consequências por elas produzidas. Dessa forma, aprender que não há possibilidade de controle, aprender a ficar inativo ou aprender a ficar mais sob controle da contiguidade, são três processos que permitem diferentes previsões em determinados arranjos experimentais.

Considerando que há dados contrários tanto à hipótese do desamparo aprendido (Glazer \& Weiss, 1976a; Lee \& Maier, 1988; Maier, Albin \& Testa, 1973; Maier \& Testa, 1975; Minor, Jackson \& Maier, 1984; Santos, Gehm \& Hunziker, 2011), quanto à hipótese da inatividade aprendida (Hunziker, 1981; Yano \& Hunziker, 2000), é possível concluir que as hipóteses até então formuladas não abrangem as variáveis críticas para a ocorrência do fenômeno, levando a necessidade de uma hipótese alternativa.

Considerando dados conflitantes com a hipótese do desamparo aprendido, Hunziker e Gehm (2010) e Santos et al. (2011) formularam uma hipótese alternativa. De acordo com os autores a exposição à incontrolabilidade sobre estímulos aversivos poderia tornar o organismo mais sensível a outras relações de controle além da consequenciação, como por exemplo, o controle por relações de contiguidade entre resposta e a consequência reforçadora negativa. Essa hipótese poderia explicar os dados obtidos por Santos et al. (2011), que mesmo tendo sido realizado levando em conta os problemas metodológicos examinados por Hunziker (1982, 2003), não puderam ser explicados a partir das hipóteses tradicionais do desamparo aprendido e da inatividade aprendida. No entanto, a hipótese proposta pelos autores ainda necessitava de uma verificação mais direta de sua adequação, objetivo proposto por este trabalho. 
Os dados da presente pesquisa sugerem que a hipótese mais adequada para descrever o fenômeno desamparo aprendido é a hipótese formulada por Hunziker e Gehm (2010) e Santos et al. (2011). Nos três experimentos realizados obteve-se que os sujeitos do Grupo I-I, mesmo com uma história prévia de exposição a choques incontroláveis, quando submetidos a uma contingência de fuga, aprenderam a resposta exigida. Ou seja, somente a exposição à incontrolabilidade não foi suficiente para que o fenômeno desamparo aprendido ocorresse, o que é contrário à hipótese do desamparo aprendido. Essa afirmação é sustentada também pelos resultados do Grupo I-A, especialmente no Experimento 3, onde a imposição de breves atrasos do reforço negativo foi capaz de produzir uma dificuldade de aprendizagem de um novo operante, em comparação aos sujeitos dos grupos N-I e N-A, não expostos previamente a choques e com os sujeitos dos grupos C-I e C-A, expostos a choques controláveis. A dificuldade de aprendizagem da resposta de focinhar apresentada pelos sujeitos do Grupo I-A, por sua vez, é contrária a hipótese da inatividade aprendida, pois a mesma exige, supostamente, um baixo grau de atividade locomotora e seria, portanto, pouco suscetível ao efeito de dificuldade de aprendizagem, o que não foi observado.

Além disso, os resultados da tríade do Experimento 3 indicam que somente os sujeitos expostos a incontrolabilidade se tornaram mais sensíveis às relações de contiguidade entre a resposta e a consequência, quando testados com um procedimento de fuga que envolvia atraso do reforço negativo. Tal delineamento possibilitou a demonstração de que o efeito do atraso do reforço sobre o comportamento dos organismos foi diferencial em relação à sua história prévia, pois os sujeitos não expostos a choques ou com história de controle sobre os choques não apresentaram dificuldade em aprender um novo operante quando atrasos do reforço negativo foram programados. 
A hipótese da contiguidade potencializada parece ter sido, portanto, aquela melhor possibilitou a interpretação dos dados obtidos nesta pesquisa e que não puderam ser explicados pelas hipóteses tradicionais. No entanto, ela suscita algumas questões que precisam ser mais bem descritas.

O elemento central nessa hipótese é o aumento de sensibilidade do organismo às relações de contiguidade. Entretanto, o termo "sensibilidade" pode inadvertidamente ser utilizado com conotação internalista de explicação do fenômeno, quando uma explicação no âmbito da Análise do Comportamento, como recomenda Skinner (1953/2003), deve se referir a relações funcionais entre resposta e aspectos do ambiente. Sendo assim, apesar da hipótese da contiguidade potencializada ter sido adequada para interpretar os resultados obtidos, é necessário também descrever as relações organismo ambiente que se estabeleceram para que os sujeitos viessem a apresentar maior sensibilidade para relações de contiguidade entre resposta e consequência.

O procedimento empregado neste estudo para verificar se ocorreria um aumento de sensibilidade às relações de contiguidade foi impor atrasos do reforço negativo em uma contingência de fuga usando organismos com diferentes histórias de exposição e controle sobre estímulos aversivos. A literatura vem demonstrando que a imposição de atrasos do reforço, além de uma redução da taxa de resposta, a partir de certo valor do atraso, provoca também a ocorrência de comportamentos supersticiosos. Keller (1966) ao impor atrasos do reforço negativo sobre a resposta de ratos de pressionar uma barra para eliminar uma luz intensa verificou que os sujeitos passaram a apresentar comportamentos supersticiosos que antecediam a consequência atrasada. Há autores, inclusive, que buscaram verificar se a redução na taxa de respostas quando atrasos do reforço são empregados decorrem da própria ocorrência de comportamentos supersticiosos que competem com a resposta definida pelo experimentador como 
elegível ao reforçamento (Schaal, Shahan, Kovera \& Reilly, 1998). Dessa forma, o emprego de atrasos do reforço para estudar o desamparo aprendido parece requerer também uma análise das possíveis seleções acidentais de comportamentos que podem ocorrer sob essas condições experimentais.

O fenômeno de seleção acidental de uma resposta devido a alterações ambientais, mesmo que independentes da resposta, tem sido objeto de investigação na Análise do Comportamento. Skinner (1948) submeteu pombos a um esquema de tempo fixo 15s (FT 15), no qual alimento era liberado em intervalos regulares independentemente da resposta apresentada pelo organismo. Como resultado, observouse que os sujeitos passaram a apresentar comportamentos específicos que antecediam a liberação do reforço. De acordo com Skinner (1948), apesar do reforço não ser produzido por qualquer resposta, ele teria aumentado a probabilidade das respostas que o antecederam, estas respostas por sua vez passaram a ter maior chance de continuar ocorrendo e sendo reforçadas.

O estudo realizado por Skinner (1948) destacou o papel da relação temporal entre resposta e evento subsequente como um aspecto importante para a efetividade da seleção de um comportamento e isso tem constituído um campo de investigação próprio. Tal variável vem sendo objeto tanto de investigações experimentais, conforme indicado por Lattal (2010) e Schneider (1990), quanto tem fundamentado propostas interpretativas de unificação dos processos de condicionamento respondente e operante, como é a proposta de Donahoe e Palmer (1994), que destaca a importância da contiguidade (e não necessariamente da relação de contingência) como condição para a seleção de comportamentos. 
A possibilidade de que haja seleção de comportamentos, mesmo em uma situação onde eventos ocorrem de forma não contingente a uma resposta específica, pode ter implicações para a compreensão do desamparo aprendido e do comportamento como um todo, assim como para os procedimentos usados para investigá-los. Considerando a história de exposição a eventos aversivos não contingentes como variável crítica para a posterior dificuldade de aprendizagem observada no desamparo aprendido, algumas questões parecem merecer um exame: (1) os procedimentos empregados para o estudo do desamparo aprendido poderiam criar condições para a seleção acidental de comportamentos? (2) a seleção acidental poderia descrever e operacionalizar os processos comportamentais responsáveis pelo aumento de sensibilidade às relações de contiguidade, hipotetizados por Hunziker e Gehm (2010) e Santos et al. (2011) como uma alternativa de explicação para o desamparo aprendido?

Para responder essas questões, é necessário examinar os procedimentos usados nessa pesquisa com o objetivo de identificar quais manipulações experimentais podem ter resultado em seleção acidental das respostas apresentadas pelo sujeito. Quanto ao Tratamento, foram utilizados dois procedimentos para criar uma situação de incontrolabilidade. No Experimento 1 foram apresentados choques elétricos de duração fixa e independentes do responder do sujeito. Nos Experimentos 2 e 3 foi usado o procedimento acoplado, onde um sujeito possuía controle sobre o choque e a distribuição, duração e intensidade dos choques recebidos por ele eram reproduzidas para um segundo sujeito, que portanto estava sujeito à incontrolabilidade. Após 24 horas foi conduzida a sessão Teste, onde metade dos sujeitos foram submetidos a uma contingência de fuga com reforçamento imediato e outra metade ao procedimento com atraso do reforço. O resultado esperado era de que os sujeitos com história de incontrolabilidade, em comparação com sujeitos ingênuos ou com história de controle 
sobre estímulos aversivos, apresentassem dificuldade na aprendizagem da nova resposta operante, sendo este efeito denominado de desamparo aprendido. No entanto, tal efeito ocorreu somente com os sujeitos com história de incontrolabilidade apenas quando a sessão Teste foi realizada se empregando atrasos do reforço negativo (Grupo I-A).

Tendo sido descritos os procedimentos para produzir e testar a ocorrência do desamparo aprendido, é possível fazer uma avaliação das condições experimentais que podem ter possibilitado os resultados obtidos nesta pesquisa. Na sessão Tratamento com choques incontroláveis, mesmo não havendo contingência, os sujeitos podem ter sido acidentalmente reforçados a emitir respostas que foram contíguas ao término do choque. Com essa história de ausência de consequenciação e exposição à contiguidade, é possível que na sessão Teste eles tenham se mantido sob controle da contiguidade entre resposta e estímulo que a segue. Aqueles que realizaram a sessão Teste sem atraso do reforço aprenderam a resposta de fuga, pois a resposta de fuga era contígua ao término do choque. Já os sujeitos que realizaram a sessão Teste com atraso do reforço apresentaram maior dificuldade em aprender a resposta de fuga, pois o procedimento possibilitava que o término do choque fosse contíguo a outra resposta, não necessariamente a de fuga. Assim, um sujeito poderia, por exemplo, introduzir o focinho no orifício do focinhador, e durante o atraso imposto experimentalmente para desligar o choque, ele poderia apresentar outra resposta (tal como retirar o focinho do focinhador), sendo ela a resposta seguida pelo término do choque e, por isso, passível de ser selecionada. Além disso, como essa resposta durante o atraso não era exigência para reforçamento, ela pode ter variado a cada choque, o que implica em que nenhuma resposta pode ter sido sistematicamente selecionada, de forma que isso apenas tornou a contingência real menos clara. 
Na sessão Tratamento com choques controláveis as condições experimentais foram diferentes, pois havia relação de dependência real entre resposta de saltar e a consequência. Como decorrência, a consequenciação pode ter se estabelecido como a relação mais funcional para o sujeito, não sendo necessário a ele ficar diferencialmente sob controle da contiguidade. Com isso, tendo essa história de relação de dependência entre responder e encerrar o choque, na sessão Teste os sujeitos novamente ficaram sob controle da consequenciação, tanto no procedimento com reforço imediato quanto com atraso do reforço.

Já os sujeitos ingênuos, sem qualquer experiência prévia com choques, se comportaram frente a eles com predominância nas relações de consequenciação, tanto no procedimento com reforço imediato quanto com atraso do reforço, possibilitando a aprendizagem operante,

Essa interpretação é compatível com a hipótese da contiguidade potencializada: sem qualquer história, ou história de reforçamento, os sujeitos são sensíveis à consequenciação; tendo uma história na qual a consequenciação estava ausente, mas havia contiguidade, esta relação se sobressai no ambiente e passa a controlar o comportamento. Se a contiguidade for sistemática após uma mesma classe de respostas, ela pode ser acidentalmente selecionada. E, a depender se é compatível ou incompatível com a resposta de fuga, pode facilitar ou dificultar a nova aprendizagem. Além dessa interferência direta de respostas, a saliência das relações de contiguidade pode dificultar, na condição de atraso, a contingência real assuma o controle do comportamento. Como decorrência, os sujeitos submetidos ao procedimento de fuga com atraso do reforço apresentaram dificuldade em aprender a resposta requerida. 
Essa interpretação é coerente também com os resultados obtidos no Experimento 3. Os sujeitos do Grupo I-A, com história de incontrolabilidade e testados com atraso foram os únicos que apresentaram dificuldade em aprender a resposta de fuga em comparação com os sujeitos expostos a choques controláveis ou a nenhum choque e que realizaram o teste tanto com atraso do reforço quanto com o reforçamento imediato.

Se for assumida essa interpretação, é possível explicar, além dos dados obtidos neste trabalho, também aqueles obtidos por Yano e Hunziker (2000) e por Santos et al. (2011). Considerando a análise de Hunziker e Gehm (2010) e de Santos et al. (2011) de que havia uma latência decorrente do uso do equipamento eletromecânico em comparação com o equipamento informatizado é possível inferir que no estudo de Yano e Hunziker (2000) o desamparo aprendido tenha ocorrido com a resposta de focinhar, pois durante a sessão Teste, o próprio equipamento impôs um atraso entre a ocorrência da resposta e a interrupção do choque, de modo que a consequência, quando apresentada, reforçou outra resposta, que não necessariamente a resposta de fuga exigida, dificultando assim sua aprendizagem. Já no estudo de Santos et al. (2011), com a utilização de equipamento informatizado, não havia atraso entre a resposta exigida no teste e a consequência, de modo que a própria resposta de focinhar era reforçada, possibilitando assim, sua aprendizagem normalmente. Em ambos os estudos, o desamparo foi obtido com a resposta de saltar, pois independentemente do equipamento utilizado, a resposta de saltar exigida no teste era consequenciada sempre com um atraso, inerente à topografia da própria resposta. Ou seja, a ocorrência do atraso do reforço acabou acidentalmente reforçando uma resposta diferente daquela exigida no teste, o que dificultou a aprendizagem da resposta de saltar.

A hipótese da contiguidade potencializada aparentemente explica as discordâncias entre os estudos de Yano e Hunziker (2000) e de Santos et al. (2011). 
Entretanto, os dados desta pesquisa não podem ser comparados por completo com os dados de Yano e Hunziker (2000), como já mencionado na Discussão do Experimento 2, dadas as diferenças no montante e na duração (fixa ou variável) de choques incontroláveis recebidos. No estudo de Yano e Hunziker (2000), no qual foi maior o montante total de choques incontroláveis recebidos, com duração fixa durante toda a sessão, o efeito de desamparo foi mais acentuado: analisando-se os desempenhos individuais, dentre oito sujeitos apenas um deles apresentou uma leve redução da latência ao longo do teste de fuga; no Experimento 3 do presente estudo, quatro dos sujeitos apresentaram redução da latência ao longo da sessão.

Outra dificuldade em estender a mesma análise para outros dados da literatura é a impossibilidade de averiguar com precisão as condições técnicas dos estudos realizados desde a década de 1960 até a implantação de controle informatizado, assim como a existência dos problemas metodológicos indicados por Hunziker (1982, 2003) que dificultam a interpretação dos resultados.

De qualquer maneira, a interpretação do desamparo aprendido a partir da seleção acidental de comportamentos parece ser adequada para descrever e operacionalizar os processos comportamentais indicados pela hipótese da contiguidade potencializada de Hunziker e Gehm (2010) e Santos et al. (2011). Tal interpretação decorrente da seleção de relações acidentais entre resposta e eventos ambientais inerentes ao procedimento é semelhante a uma das interpretações para explicar o desamparo aprendido, denominada hipótese da inatividade aprendida (Glazer \& Weiss, 1976a). No entanto, há diferenças na forma de explicar o desamparo aprendido a partir da hipótese da inatividade aprendida e da hipótese da contiguidade potencializada. 
A hipótese da inatividade aprendida supõe que na sessão Tratamento, necessariamente, ocorre punição acidental de respostas de alta atividade motora, como seriam as respostas eliciadas pelo choque: respostas de saltar, correr, levantar-se sobre as patas traseiras etc. Supõe ainda o reforçamento acidental de respostas de baixa atividade locomotora, como permanecer imóvel. Como decorrência, na sessão Teste, o sujeito teria fortalecido um repertório de baixa locomoção, o que interferiria com a aprendizagem da resposta exigida no Teste, especialmente quando este exige alta atividade locomotora. Sendo assim, o grau de atividade motora apresentado pelo indivíduo é a variável crítica nessa hipótese.

A relevância do grau de atividade locomotora foi submetida sistematicamente à verificação experimental em alguns estudos e não foi confirmada. Por exemplo, o estudo de Hunziker (1981) indica que independentemente da resposta apresentada pelo sujeito durante os choques incontroláveis (correr ou ficar parado), a variável relevante para a posterior dificuldade na aprendizagem de fuga foi uma história de incontrolabilidade. Yano e Hunziker (2000) também não encontraram diferenças no comportamento dos sujeitos que realizaram o teste de fuga com resposta de supostamente alta atividade locomotora (saltar) e baixa atividade locomotora (focinhar). Dessa forma, os resultados desses estudos enfraquecem a hipótese da inatividade aprendida ao não verificar que o efeito de dificuldade de aprendizagem é dependente do grau de atividade locomotora da resposta apresentada pelo organismo.

Mesmo com dados contrários à hipótese da inatividade aprendida, a questão da influência da seleção acidental do comportamento durante a exposição a choques incontroláveis parece ser uma variável que não pode ser completamente desconsiderada. Diferentemente da hipótese da inatividade aprendida, a interpretação da seleção acidental não releva importância para o grau de atividade locomotora apresentado pelo 
sujeito durante as condições experimentais. $\mathrm{O}$ aspecto central se refere apenas à importância de identificar a seleção acidental de um repertório que pode competir com a resposta exigida no teste, independentemente do grau de atividade locomotora da resposta de fuga. Dito de outra forma, o efeito de desamparo seria decorrente não necessariamente da redução da atividade locomotora, mas sim da sensibilidade às relações de contiguidade selecionadas acidentalmente durante o tratamento com choques incontroláveis.

A ocorrência do desamparo aprendido apenas quando foi utilizado atraso do reforço na sessão Teste com sujeitos com história de incontrolabilidade reitera a importância de investigar possíveis relações acidentais do comportamento. Na área de estudos que investiga o atraso do reforço, uma das linhas de investigação se refere justamente à demonstração de que o efeito do atraso do reforço de reduzir a taxa de respostas de um operante se deve ao fortalecimento acidental de respostas que competem com a resposta elegida para o reforço (Lattal, 2010; Schaal et al., 1998). No caso das condições experimentais deste estudo, quando empregado atraso do reforço, foi possível observar de forma assistemática que o sujeito apresentava a resposta de focinhar e o choque permanecia devido ao atraso. Isso fazia com que o sujeito apresentasse outra resposta, como tirar o focinho do orifício do focinhador e ficar sobre as patas traseiras, momento no qual ocorria o término do choque. Uma possibilidade é que estas respostas estariam sendo acidentalmente reforçadas e dificultando a aprendizagem da resposta de focinhar, exigida como fuga.

Apesar de plausível e de haver sustentação na literatura para esta interpretação, há algumas ressalvas a serem feitas quanto à limitação deste estudo em sustentar tal interpretação. Não foi realizado, em nenhum dos experimentos, algum tipo de registro de possíveis comportamentos supersticiosos apresentados pelos sujeitos. Para dar maior 
sustentação a esse tipo de interpretação se faz necessário conduzir novos estudos experimentais que usem procedimentos para colocar tal variável sob controle experimental, como por exemplo, registrar e mensurar respostas que podem estar sendo selecionadas acidentalmente.

Mesmo com esta limitação, esta discussão tem o objetivo de evidenciar a necessidade de controle de uma variável possivelmente interveniente, o que pode trazer contribuições metodológicas para a área de estudo do desamparo aprendido. O reconhecimento de relações acidentais parece ser importante para avaliar a adequação dos próprios procedimentos utilizados na investigação do desamparo aprendido. Como já alertado por Hunziker (1982), apesar da incontrolabilidade ser definida teoricamente como uma situação de igualdade entre as probabilidades de ocorrência do estímulo dada a ocorrência ou não de uma resposta, operacionalmente os procedimentos geralmente empregados (com exceção de Hunziker, 1981) utilizam um critério temporal para apresentação e remoção do choque, sem controle da resposta apresentada pelo organismo na ocasião desses eventos. Sem essa medida de controle experimental, é possível que ocorram seleções acidentais de diferentes classes de respostas, a depender das respostas apresentadas pelo sujeito, que podem interferir no posterior desempenho no teste de fuga. Esse aspecto poderia estar relacionado, por exemplo, à considerável variabilidade em todos os três experimentos quando se observa o desempenho dos sujeitos do Grupo I-A, expostos aparentemente às mesmas condições experimentais.

Nesse sentido, o delineamento proposto por Hunziker (1981) que cria as condições experimentais equivalentes à definição de incontrolabilidade como igualdade entre as probabilidades de ocorrência do estímulo dada a ocorrência ou não de uma resposta, parece ser relevante se considerada a possibilidade de colocar sob controle experimental a ocorrência de respostas contíguas às alterações ambientais ocasionadas 
pelo procedimento de incontrolabilidade. Em seu estudo, foi colocada sob controle experimental a ocorrência ou não da resposta de correr na roda de atividade durante a apresentação do choque, que seria um das alterações ambientais relevantes. Uma possibilidade de aperfeiçoamento do procedimento poderia ser controlar a ocorrência ou não de uma resposta diferente durante a remoção do choque. Por exemplo, o experimentador poderia controlar a resposta de correr na roda de atividade durante a apresentação do choque e forçar o travamento da roda de atividade instantes antes da remoção do choque.

Tal delineamento poderia ser utilizado para testar outras combinações de respostas contíguas às alterações ambientais decorrentes do procedimento, de forma a verificar diretamente a influência da seleção acidental de comportamentos na ocorrência do desamparo aprendido. Apesar de Hunziker (1981) não ter verificado uma relação sistemática entre atividade apresentada pelos sujeitos durante a exposição aos choques e dificuldade de aprendizagem, o grau de atividade não foi irrelevante por completo, uma vez que o desempenho dos grupos diferiu em relação ao grau de atividade locomotora exigida. Esse procedimento chama atenção para a necessidade do registro de outras respostas, que não apenas a resposta de fuga. Somente dessa forma poderia ser verificada sistematicamente a seleção acidental de respostas.

Uma segunda possibilidade de interpretação para a ocorrência da dificuldade de aprendizagem somente dos sujeitos do Grupo I-A, pode ser a semelhança funcional entre as condições experimentais das sessões de Tratamento e Teste quando usado atraso do reforço. De acordo com Schaal et al., (1998) tanto o procedimento de apresentação não contingente de um estímulo (empregado no Tratamento), quanto o procedimento de atraso do reforço (empregado no Teste) são similares, pois, o experimentador abdica do controle sobre as respostas que ocorrem no momento da 
apresentação do estímulo. Com isso, os autores sugerem que comportamentos supersticiosos poderiam ocorrer em ambas as condições. No caso da sessão Tratamento esse efeito passa despercebido pelo experimentador, uma vez que nenhuma resposta do sujeito é registrada. No entanto, na sessão Teste a ocorrência de comportamentos supersticiosos poderia competir com a resposta de fuga exigida.

Este estudo parece propiciar a realização de investigações futuras para identificar com maior clareza e precisão quais são os processos comportamentais que de fato levam um organismo a se tornar mais sensível às relações de contiguidade. Seria a exposição à incontrolabilidade suficiente para que o organismo aprenda a ficar sob controle da contiguidade? Seria necessária a ocorrência de supersticiosos? Como mensurá-los e identificar sua influência em aprendizagens posteriores? Esses processos ocorrem de maneira análoga em humanos? Nesses casos, haveria interação com outras variáveis, como por exemplo, o comportamento verbal? Como se dá essa interação?

Em síntese, as dados obtidos sugerem que a hipótese formulada por Hunziker e Gehm (2010) e Santos et al. (2011) parece ser a mais adequada para explicar o desamparo aprendido. Tal hipótese configura uma contribuição a ser mais bem investigada na área, pois pode subsidiar novas possibilidades de análise experimental do fenômeno denominado desamparo aprendido. Entre as possibilidades se destaca o papel que a seleção acidental do comportamento que pode exercer sobre a ocorrência deste fenômeno. 


\section{REFERÊNCIAS}

Abreu, P. R. (2011). Novas relações entre as interpretações funcionais do desamparo aprendido e do modelo comportamental de depressão. Psicologia Reflexão $e$ Crítica, 24(4), 788-797.

Botomé, S. P. (2013). O conceito de comportamento operante como problema. Revista Brasileira de Análise do Comportamento, 9(1), 19-46.

Catania, A. C. (1999). Aprendizagem: Comportamento, linguagem e cognição. Porto Alegre: Artmed.

Donahoe, J. W., \& Palmer, D. C. (1994). Learning and complex behavior. V. P. Dorsel (Ed.). Boston, MA: Allyn and bacon.

Ferster, C. B., \& Skinner, B. F. (1957). Schedules of reinforcement. New York: Appleton-Century-Crofts.

Fowler, H.; Trapold, M. A. (1962). Escape performance as a function of delay of reinforcement. Journal of Experimental Psychology, 63, 464-467.

Glazer, H. I, \& Weiss, J. M. (1976a). Long-term interference effect: an alternative to "learned helplessness". Journal of Experimental Psychology: Animal Behavior Processes, 2(3), 202-213.

Glazer, H. I., \& Weiss, J. M. (1976b). Long-term and transitory interference effects. Journal of Experimental Psychology: Animal Behavior Processes, 2(3), 191201.

Haaren, F. V. (1992). Response acquisition with fixed and variable resetting delays of reinforcement in male and female Wistar rats. Physiology \& Behavior, 52(4), 767772 .

Hunziker, M. H. L. (1982). Considerações metodológicas sobre o estudo da incontrolabilidade. Psicologia, 8(3), 61-77.

Hunziker, M. H. L. (1977). Efeitos da exposição prévia a choques não contingentes sobre aquisição do comportamento de fuga como função de algumas dimensões da resposta. Dissertação de Mestrado. São Paulo: Universidade de São Paulo.

Hunziker, M. H. L. (1981). Um estudo sobre a incontrolabilidade: considerações metodológicas, uma análise experimental. Tese de Doutorado. São Paulo: Universidade de São Paulo.

Hunziker, M. H. L. (1982). Considerações metodológicas sobre o estudo a incontrolabilidade. Psicologia, 8(3), 61-77.

Hunziker, M. H. L. (2003). Desamparo aprendido. Tese de livre docência. Instituto de Psicologia, Universidade de São Paulo, São Paulo, SP, Brasil. 
Hunziker, M. H. L. (2005). O desamparo aprendido revisitado: estudos em animais. Psicologia: Teoria e Pesquisa, 21(2), 131-139.

Hunziker, M. H. L., \& Santos, C. V. (2007). Learned helplessness: effects of response requirement and interval between treatment and testing. Behavioural Processes, 76(3), 183-191.

Hunziker, M. H. L.; Gehm, T. P. (2010). Uma nova interpretação sobre o desamparo aprendido. In: Cillo, E.; Garcia, M. R.; Abreu; P. Faleiros, P.. (Org.). Sobre Comportamento e Cognição, 23, 352-360.

Keller, J. V. (1966). Delayed escape from light by the albino rat. Journal of the Experimental Analysis of Behavior, 9(6), 655-658.

Lattal, K. A. (2010). Delayed reinforcement of operant behavior. Journal of the Experimental Analysis of Behavior, 93(1), 129-139.

Lee, R. K, K. \& Maier, S. F. (1988). Inescapable shock and attention to internal versus external cues in a water discrimination escape task. Journal of Experimental Psychology: Animal Behavior Processes, 14(3), 302-310.

Maier, S. F. Albin, R. W. \& Testa, T. J. (1973). Failure to learn to escape in rats previously exposed to inescapable shock depends on nature of escape response. Journal of Comparative and Physiological Psychology, 85(3), 581-592.

Maier, S. F. \& Testa, T. J. (1975). Failure to learn to escape by rats previously exposed to inescapable shock is partly produced by associate interference. Journal of Comparative and Physiological Psychology, 88(2), 554-564.

Maier, S, F. \& Seligman, M. E. P. (1976). Learned helplessness: theory and evidence. Journal of Experimental Psychology: General, 105(1), 3-46.

Maier, S. F. (1984). Learned helplessness and animal models of depression. Progress in Neuro-Psychopharmacology and Biological Psychiatry, 8(3), 435-446.

Minor, T. R., Jackson, R. L., \& Maier, S. F. (1984). Effects of Task-Irrelevant Cues and Reinforcement Delay on Choice-Escape Learning Following Inescapable Shock: Evidence for a Deficit in Selective Attention. Journal of Experimental Psychology: Animal Behavior Processes, 10(4), 543-556.

Overmier, J. B., \& Seligman, M. E. (1967). Effects of inescapable shock upon subsequent escape and avoidance responding. Journal of comparative and physiological psychology, 63(1), 28-33.

Peterson, C., Maier, S. F., \& Seligman, M. E. P. (1993). Learned helplessness: A theory for the age of personal control. New York: Oxford University Press.

Reilly, M. P., \& Lattal, K. A. (2004). Within-session delay-of-reinforcement gradients. Journal of the Experimental Analysis of Behavior, 82(1), 21-35. 
Santos, C. V., Gehm, T. P., \& Hunziker, M. H. L. (2011). Learned helplessness in the rat: Effect of response topography in a within-subject design. Behavioural Processes, 86, 178-186.

Schaal, D. W., Shahan, T. A., Kovera, C. A., \& Reilly, M. P. (1998). Mechanisms underlying the effects of unsignaled delayed reinforcement on key pecking of pigeons under variable-interval schedules. Journal of the Experimental Analysis of Behavior, 69(2), 103-122.

Schneider, S. M. (1990). The role of contiguity in free-operant unsignaled delay of positive reinforcement: A brief review. The Psychological Record, 40(2), 239.

Seligman, M. E. P. \& Maier, S. F. (1967). Failure to escape traumatic shock. Journal of Experimental Psychology, 74(1), 1-9.

Seligman, M. E., Maier, S. F., \& Geer, J. H. (1968). Alleviation of learned helplessness in the dog. Journal of abnormal Psychology, 73(3), 256-262.

Skinner, B. F. (1948). 'Superstition' in the pigeon. Journal of Experimental Psychology, 38(2), 168-172.

Skinner, B. F. (2003). Ciência e comportamento humano. São Paulo: Martins Fontes. (Trabalho original publicado em 1953)

Wilkenfield, J., Nickel, M., Blakely, E., \& Poling, A. (1992). Acquisition of lever-press responding in rats with delayed reinforcement: a comparison of three procedures. Journal of the Experimental Analysis of Behavior, 58(3), 431-443.

Yano, Y \& Hunziker, M. H. L. (2000). Desamparo aprendido e imunização com diferentes respostas de fuga. Acta comportamentalia, 8(2), 143-166. 